\title{
The New Common Minimum Anti-Abuse Rule in the EU Parent-Subsidiary Directive: Background, Impact, Applicability, Purpose and Effect
}

\section{Dennis Weber*}

\section{INTRODUCTION}

Due to an amendment of the Parent-Subsidiary Directive, the EU Member States must include a 'common minimum anti-abuse rule' in their legislation for situations that fall under the Parent-Subsidiary Directive (dividend payments between EU subsidiaries and EU parent companies) by 31 December 2015 at the latest. ${ }^{1}$ With this amendment, it is the first time that it has become mandatory to incorporate a General Anti-Abuse Rule (GAAR) in the tax legislation of the EU Member States. In this paper, I deal with the background, impact, applicability, purpose and effect of the amendment.

\section{History OF THE FORMATION OF THE COMMON ANTI-ABUSE RULE}

In November 2013, the European Commission put forward a proposal to incorporate in the Parent-Subsidiary Directive (also referred to as: 'PSD') (i) a general antiabuse provision, and (ii) a provision that had to combat the advantage of hybrid financial mismatches (hereafter: the November 2013 proposal). ${ }^{2}$ Subsequently, the Member
States failed to reach consensus on the formulation of the common anti-abuse provision thus, in Directive 2014/86/ EU of 8 July $2014,{ }^{3}$ an amendment of the ParentSubsidiary Directive was adopted, which was only directed against mismatches, which arose through the effect of hybrid instruments. The reason that no agreement could be reached on the common anti-abuse rule was that some Member States raised concerns 'that a common anti-abuse rule may not be efficient in terms of its application, because it might be too general or, conversely, too restrictive and, therefore, not likely to address all abusive practices. This would make it preferable to leave the prevention of abusive practices to the competence of national jurisdictions, as opposed to Union legislation'4. Also, the fact that the Commission proposal contained a list of situations, which pointed to abuse was perceived by some Member States as being too generic and not sufficiently tailored to cover specific PSD situations. ${ }^{5}$

The Italian Presidency of the EU Council then put forward a proposal for a new anti-abuse rule, ${ }^{6}$ which after some amendments, ${ }^{7}$ resulted in a definitive text in November $2014,{ }^{8}$ on which a political agreement was reached in December 2014.9 In January 2015, this text was adopted by the ECOFIN and on 28 January 2015,

\section{Notes}

Director Amsterdam Centre for Tax Law (ACTL); University of Amsterdam; counsel Loyens \& Loeff.

Council Directive (EU 2015/121 of January 2015 amending Directive 2011/96/EU on the common system of taxation applicable in the case of parent companies and subsidiaries of different Member States, OJ2015 L21/1.

Brussels, 25 Nov. 2013, COM (2013) 814 final, HEI 2014/74 (comments by Dennis Weber).

Council Directive 2014/86/EU of 8 Jul. 2014 amending Directive 2011/96/EU on the common system of taxation applicable in the case of parent companies and subsidiaries of different Member States, OJ L 2014/219.

See: Room document \# 1, Working party on Tax Questions - Direct Taxation, PSD - Anti-abuse rule, 24 Jul. 2014, p. 2, published in: Highlights \& Insights on European Taxation, H\&I 2015/274 (comments by Dennis Weber).

See: Room document \# 1, Working party on Tax Questions - Direct Taxation, PSD - Anti-abuse rule, 24 Jul. 2014, p. 2 and 3, published in: Highlights \& Insights on European Taxation, H\&I 2015/274 (comments by Dennis Weber) and Room document \# 3, Working party on Tax Questions - Direct Taxation, PSD - Anti-abuse rule, 17 Sep. 2014, p. 2, published in: Highlights \& Insights on European Taxation, H\&I 2015/275 (comments by Dennis Weber).

See: Room document \# 1, Working party on Tax Questions - Direct Taxation, PSD - Anti-abuse rule, 24 Jul. 2014, published in: Highlights \& Insights on European Taxation, H\&I 2015/274 (comments by Dennis Weber).

See: Room document \# 3, Working party on Tax Questions - Direct Taxation, PSD - Anti-abuse rule, 17 Sep. 2014, published in: Highlights \& Insights on European Taxation, H\&I 2015/275 (comments by Dennis Weber).

See: Brussels, 4 Nov. 2014, 14950/14, FISC 182, ECOFIN 1002 and Presidency compromise, Brussels 4 Nov. 2014, no. 14531/1/14, FISC 165, ECOFIN 953.

Political agreement, Brussels 5 Dec. 2014, no. 16435/14, adopted at the 3356th Council meeting, Council of the European Union, Brussels 9 Dec. 2014, no. 16603/14, p. 20. 
published in the EU Official Journal. ${ }^{10}$ This amendment of the Parent-Subsidiary Directive must be implemented in the legislation of the Member States by 31 December 2015 at the latest. With regard to the interpretation of the amendment, it is important to note that no explanatory memorandum to the amendment of the directive was published. Therefore, we have to rely on the considerations in the preamble for an interpretation. The preamble provides a further explanation of the scope, purpose and reasons for the amendment, and gives an example of abuse.

In addition, there are a number of other documents, which can be of assistance in an interpretation of the directive. First, an Impact Assessment was published with the November 2013 proposal $^{11}$ (there was no impact assessment with the amended Italian Presidency proposal). Second, there are two Room Documents of the Italian Presidency to the Working Party on Tax Questions (WPTQ), in which the proposed amendment is discussed. ${ }^{12}$ Comments have also been made in the conclusions of the ECOFIN meeting of 9 December 2014, to which a Statement of the European Commission was also added. ${ }^{13}$ There are also Memos with questions and answers from the European Commission from which inspiration can be drawn. ${ }^{14}$

I shall revert to all those documents/memo's/comments in this paper (and discuss the value that can be attributed to them), but I will now observe that the CJ does indeed attach value 'if appropriate' to the 'the origin of those rules' 15 and thus, applies a (historical) interpretation on the basis of all sorts of preparatory documents (travaux préparatoires) and remarks in the EU Council, but there again it must be noted that the $\mathrm{CJ}$ is reticent ${ }^{16}$ and first favour an interpretation on the basis of the wording of the law (literal interpretation), the context of the law (systematic interpretation) and, most important in the light of the purpose of the law (teleological interpretation). We see that, for example, in the Epson case, which case concerned the PSD, and in which the CJ ruled: ${ }^{17}$ 'As regards the Portuguese Government's argument that it is clear from various documents and, in particular, from a declaration of the Council that ISD was excluded from the scope of Article 5(1) of the Directive, there is no basis for that contention in the wording of the Directive. Moreover, according to settled case-law, declarations recorded in Council minutes in the course of preparatory work leading to the adoption of a directive cannot be used for the purpose of interpreting that directive where no reference is made to the content of the declaration in the wording of the provision in question, and, moreover, such declarations have no legal significance'. See also Denkavit-VITC-Voormeer, ${ }^{18}$ another case concerning the PSD Directive. Declarations in Council minutes, expression of intent of the Member State, press releases, ${ }^{19}$ etc. must thus be expressed in the directive text itself. Such like expressions may only elucidate further on a directive provision when this is unclear, may not fill any gaps in directive provisions and may not, according to AG Darmon, ${ }^{20}$ be the sole explanatory instrument in order to come to a certain interpretation of a directive. ${ }^{21}$

\section{Notes}

10 Council Directive 2015/121 of 27 Jan. 2015 amending Directive 2011/96/EU on the common system of taxation applicable in the case of parent companies and subsidiaries of different Member States, OJ 2015 L21/1.

11 Commission staff working document, Impact Assessment, 25 Nov. 2013, SWD (2013) 474 final.

12 See: Room document \# 1, Working party on Tax Questions - Direct Taxation, PSD - Anti-abuse rule, 24 Jul. 2014, published in: Highlights \& Insights on European Taxation, H\&I 2015/274 (comments by Dennis Weber) and Room document \# 3, Working party on Tax Questions - Direct Taxation, PSD - Anti-abuse rule, 17 Sep. 2014 , published in: Highlights \& Insights on European Taxation, H\&I 2015/275 (comments by Dennis Weber).

13 See: Political agreement, Brussels 5 Dec. 2014, no. 16435/14, adopted at the 3356th Council meeting, Council of the European Union, Brussels 9 Dec. 2014, no. 16603/ 14 , p. 20.

14 See: Question and Answers on the Parent-Subsidiary Directive, Brussels, 25 Nov. 2013, MEMO/13/1040 and Questions and answers on tax transparency, 18 Mar. 2015, MEMO/15/4609.

15 See: CJ 22 Apr. 2015, C-357/13 Drukarnia Multipress, para. 22

16 According to Schermers/Waelbroeck can only by way of exception travaux préparatoires be used in interpreting Community law; see: H.G. Schermers \& D.F. Waelbroeck, Judicial Protection in the European Union 16 (Kluwer Law International 2001).

17 CJ 8 Jun. 2000, case C-375/98, para. 26.

1817 Oct. 1996, joined cases C-283/94, C-291/94 and C-292/94 Denkavit-VITIC-Voormeer, para. 29.

19 See CJ 17 Apr. 2008, C-404/06 Quelle, in which for the interpretation of a provision in a directive the German government invoked a press release from the 'Parliament Council' Conciliation Committee (para. 37).

20 See Opinion of AG Darmon of 8 Nov. 1990, in case C-291/89, Antonissen, point 27: 'I therefore conclude that a declaration of the Council entered in its minutes can constitute a guide for the interpretation of provisions of a measure of secondary legislation the drawing up or adoption of which gave rise to that declaration, only in so far as the aim is to clarify the meaning of those provisions which are ex hypothesi ambiguous or equivocal'.

21 See also AG Trstenjak in Opinion in case C-404/06, Quelle, point 59: 'It should also be emphasized that even if a historical interpretation is thought to point to the result suggested by the German Government, that method of interpretation is not sufficient in itself and cannot be decisive, because it plays only a subsidiary role in the interpretation of Community law. The true meaning of rules of Community law can be derived only from those rules themselves, in the light of their context and purpose'. 


\section{The ANTI-ABUSE PROVISIONS IN THE PARENT-SUBSIDIARY DIRECTIVE AFTER THE AMENDMENTS}

\section{I Text}

After the amendment, two anti-abuse provisions have been included in Article 1, paragraph 2 through paragraph 4 of the Parent-Subsidiary Directive.

Article 1, paragraphs 2 and 3 contain the new general anti-abuse provision, implementation of which is mandatory:

2. Member States shall not grant the benefits of this Directive to an arrangement or a series of arrangements which, having been put into place for the main purpose or one of the main purposes of obtaining a tax advantage that defeats the object or purpose of this Directive, are not genuine having regard to all relevant facts and circumstances. An arrangement may comprise more than one step or part.

3. For the purposes of paragraph 2, an arrangement or a series of arrangements shall be regarded as not genuine to the extent that they are not put into place for valid commercial reasons which reflect economic reality.

In Article 1, paragraph 4 of the directive after the amendment, the old (non-mandatory) anti-abuse provision, is included:

'This Directive shall not preclude the application of domestic or agreement-based provisions required for the prevention of tax evasion, tax fraud or abuse.'

\subsection{Purpose of the Amendment}

Implementation of the general anti-abuse provision in the national law of a Member State is mandatory. This is clear from the text of Article 1, paragraph 2: 'Member States shall not grant the benefits of this Directive'. The object of the general anti-abuse provision is to prevent abuse of the Parent-Subsidiary Directive. The reason for including a mandatory provision is worded clearly in the preamble: first, it is pointed out that 'Some Member States apply domestic or agreement-based provisions aimed at tackling tax evasion, tax fraud or abusive practices in a general or in a specific way'.22 In this framework, in the impact assessment to the first version of the general anti-abuse provision of November 2013, the general anti-abuse provisions of France and Germany ${ }^{23}$ were mentioned as examples.

In addition, it is observed in the preamble of the directive that there is no uniformity in the various antiabuse provisions of the Member States: 'However, those provisions may have different levels of severity and, in any case, they are designed to reflect the specificities of each Member State's tax system'; it is also raised that anti-abuse provisions are sometimes lacking: 'Moreover, some Member States do not have any domestic or agreementbased provisions for the prevention of abuse'. ${ }^{24}$ In the impact assessment of November 2013, Denmark is mentioned here as example: 'other Member States, such as Denmark, do not have a legislative general anti-abuse rule, but rely on other measures like domestic case law against abuse'.

It is also remarked in the preamble to the directive: 'Therefore, the inclusion of a common minimum antiabuse rule in Directive 2011/96/EU would be very helpful to prevent misuse of that Directive and to ensure greater consistency in its application in different Member States'.

The Italian Presidency described their proposal as a 'common minimum anti-abuse rule' 'which is aimed at supplementing, without replacing, the domestic and agreement-based provisions to prevent tax avoidance, thereby granting a minimum EU standard for the purposes of protecting the PSD'. ${ }^{25}$

The Presidency also gave the following additional explanations: ${ }^{26}$

- The inclusion of a common anti-abuse provision in the PSD would be highly beneficial, in the Presidency's view, even if some Member States already have domestic anti-abuse rules. In effect, not all Member States have domestic provisions for the prevention of abuse and these provisions may have different severity and, in any case, they are designed to reflect the specificities of each Member State's tax system. Therefore, an anti-abuse provision in the PSD would guarantee a minimum level of protection of the Directive against abuse, thereby overcoming

\section{Notes}

\footnotetext{
3rd consideration in the Preamble.

Commission staff working document, Impact Assessment, 25 Nov. 2013, SWD (2013) 474 final.

4th consideration in the Preamble.

See: Room document \# 1, Working party on Tax Questions - Direct Taxation, PSD - Anti-abuse rule, 24 Jul. 2014, p. 2, published in: Highlights \& Insights on European Taxation, H\&I 2015/274 (comments by Dennis Weber).

26 See: Room document \# 3, Working party on Tax Questions - Direct Taxation, PSD - Anti-abuse rule, 17 Sep. 2014, p. 3, published in: Highlights \& Insights on European Taxation, H\&I 2015/275 (comments by Dennis Weber)
} 
the inefficiencies arising from the misalignments in the approaches taken by Member States to tackle abusive practices.

- The proposed anti-abuse provision would not affect in any way Member States' ability to apply domestic or agreement-based provisions aimed at tackling tax evasion, tax fraud and abuse. As explained by the Commission at the meeting of 24 July, if a Member States already has a domestic anti-abuse provision which is at least as strict as the proposed minimum standard, no further action is required by that Member State to implement the anti-abuse rule in the PSD. If a Member State does not have any domestic anti-abuse provision or has an anti-abuse provision which is less strict than the proposed de minimis rule, only in these circumstances a Member State would need to transpose in its domestic law the anti-abuse provision included the PSD.

- The proposed anti-abuse rule would not unduly interfere with Member States' policies on anti-abuse as the rule is not aimed at generically combating abusive practices, but only those implying a violation of the scope and purpose of the PSD. Therefore, domestic anti-abuse provisions would continue to apply to non-PSD related situations (and also to cases covered by the PSD, if they provide for a level of protection that is at least as strict as the proposed de minimis rule).

- The CJEU would ensure a uniform interpretation of a common anti-abuse provision included in the PSD. In any event, the inclusion of an anti-abuse rule in the PSD would, by itself, increase legal certainty.

The Council High Level Working Party on Tax issues (HLWP) summarized this as follows: 'The proposed antiabuse rule, by filling the gaps arising from the misalignments in Member States' rules aimed at tackling abusive practices, would provide a common minimum level of protection of the PSD against abuses. Such a rule would only come into play if and to the extent that the Member State concerned does not have a domestic antiabuse rule or has a domestic anti-abuse rule, which is less strict than the proposed "minimum standard"'.27

As reasons why the Member States did agree with the current common minimum anti-abuse rule and not with the November 2013 proposal of the European Commission it was argued ${ }^{28}$ that there was a: (i) 'de minimis approach'; (ii) which gives adequate protection to the PSD without affecting Member States' domestic or agreement-based anti-abuse provisions; (iii) that it includes a 'main purpose test' which goes in the direction followed by the OECD in its parallel work on BEPS; and (iv) that it does not include the list with tax avoidance examples proposed by the Commission.

This apparently is to meet the previous objections that had been made to the Commission proposal of November 2013. It must be noted that the impression is also, that given the fact that the political landscape at that moment in some Member States had changed to such extent, some Member States, on the basis of political considerations, have agreed to a common anti-abuse rule. ${ }^{29}$

\subsection{The New Context of the Anti-abuse Provisions in the Directive}

After the amendment of the Parent-Subsidiary Directive on the basis of Article 1, paragraphs 2 and 3, a mandatory general anti-abuse provision must be transposed in the legislation of the Member States. In addition, the Member States may also, on the basis of the old anti-abuse provision of Article 1, paragraph 4 combat (nonmandatory), abuse. Article 1, paragraph 4 reads: 'This Directive shall not preclude the application of domestic or agreement-based provisions required for the prevention of tax evasion, tax fraud or abuse.' A minor amendment has been added, as compared to the old non-mandatory antiabuse provision, namely that 'tax evasion' may also be combated. It is unclear why both 'tax evasion' and 'tax fraud' are now mentioned, given that these two terms would seem to have the same meaning and thus, there is an overlap. The explanation of this overlap could be that in the November 2013 proposal, the European Commission proposed to limit the non-mandatory antiabuse provision to measures against 'tax evasion'. In the Commission proposal thus, a broad mandatory anti-abuse provision was included against abuse (tax avoidance) and in addition, the Member States were allowed to combat non-mandatory only tax evasion. That in addition to the mandatory combating of abuse the Member States were not allowed to independently take measures against tax avoidance (but only against tax evasion) was a step too far for some Member States. ${ }^{30}$ The Italian Presidency thereupon decided to add the old wording (tax fraud or abuse) of the non-mandatory anti-abuse provisions again to the proposal. Due to this, there was thus an overlap

\section{Notes}

See point 25 of the ECOFIN Report to the European Council on Tax issues, General Secretariat of the Council, Brussels, 11 Dec. 2014 , no. 16753/14.

28 See: Room document \# 3, Working party on Tax Questions - Direct Taxation, PSD - Anti-abuse rule, 17 Sep. 2014, p. 2, published in: Highlights \& Insights on European Taxation, H\&I 2015/275 (comments by Dennis Weber).

29 See, for instance, the remark of O.C.R. Marres \& I.M. de Groot, De algemene antimisbruikbepaling in de moeder-dochterrichtlijn (deel 1), WFR 2015/7106, p. 888.

30 See: Room document \# 3, Working party on Tax Questions - Direct Taxation, PSD - Anti-abuse rule, 17 Sep. 2014, p. 1, published in: Highlights \& Insights on European Taxation, H\&I 2015/275 (comments by Dennis Weber). 
with tax evasion (which was already in the Commission proposal) and the added tax fraud.

The question is how the mandatory common minimum anti-abuse rule and the non-mandatory anti-abuse rule relate to each other. On this, the Presidency observed: 'The proposed new paragraph 4 aims at clarifying that the general anti-abuse rule does not affect the application of domestic or agreement-based provisions required for the prevention of fraud, tax abuse and tax evasion. On the contrary, the clause is aimed at making up for any absence or inadequacy of domestic rules. In other words, the clause would apply in cases where the Member States concerned do not have any domestic anti-abuse provisions or have domestic anti-abuse rules that do not cover situations covered by the PSD or that are less strict than the "minimum standard" proposed for inclusion in the revised PSD'. 31

The Presidency pointed out that on the basis of Article 1, paragraph 4, the Member States may also in situations that fall outside of the scope of the Parent-Subsidiary Directive apply domestic national anti-abuse rules. This, however, is self-evident, given that when the ParentSubsidiary Directive is not applicable, Member States remain free in how they apply their national tax system (including anti-abuse measures); Article 1, paragraph 4 is not necessary for this (Article 1, paragraph 4 is then not even applicable). Another remark of the Presidency is that on the basis of Article 1, paragraph 4, the Member States may take measures 'that are less strict than the "minimum standard"'. It would seem thus to follow from this that the Member States must follow the common minimum standard of Article 1, paragraph 2, on the one hand, but, on the other, they also remain free in certain areas to include less strict anti-abuse provisions. I only wonder how I should imagine this precisely. Does this mean that the Member States, for example, must include the common minimum anti-abuse rule in their legislation and in addition, may include more direct anti-abuse provisions in their legislation (for example, against dividend stripping)?32 It would seem from the remarks of the Presidency, however, that it must follow anyway that on the basis of Article 1, paragraph 4 no more abuse may be combated than that permitted in Article 1, paragraph 2. I revert to this in paragraph 4 .

What is clear in all events is that the Member States on the basis of Article 1, paragraph 4 may take measures against tax fraud/tax evasion.

I also note that in addition to this, specific anti-abuse measures have also been included in the directive itself. For example, in Article 2(a) (iii) a subject to tax rule is included, in Article 3(2) an optional minimum holdings period of two years, and in Article 4(1) the anti-hybrid instruments rule. With regard to the minimum holdings provision of Article 3(2), the CJ had already observed in Denkavit-VITC-Voormeer ${ }^{33}$ that Article 1(4) (the old nonmandatory anti-abuse rule) was a 'provision of principle', the content of which is explained in detail in Article 3(2) thereof. The minimum holdings period is aimed in particular at counteracting abuse whereby holdings are taken in the capital of companies for the sole purpose of benefiting from the tax advantages available and which are not intended to be lasting'. This raises the question, when a Member State has not implemented the minimum holding period of Article 3(2) and thus allows the possibility of abuse for which that provision provides, if after the introduction of the common anti-abuse rule this Member State will be obliged to combat that type of abuse $^{34}$

\section{De minimis RULe - No CARTe blanche for NATIONAL LEGISLATURE}

The reason for the mandatory common minimum antiabuse rule is to ensure that all Member States combat abuse under the same conditions and thus, achieving consistency (see further 3.2).

In the conclusions of the ECOFIN of 9 December 2014, in which a political agreement was reached on adoption of the amending directive it was noted that the new general anti-abuse provision is a 'de minimis rule', which is 'allowing countries to apply stricter national rules, as long as they meet minimum EU requirements'. 35,36

\section{Notes}

31 See: Room document \# 1, Working party on Tax Questions - Direct Taxation, PSD - Anti-abuse rule, 24 Jul. 2014, p. 4, published in: Highlights \& Insights on European Taxation, H\&I 2015/274 (comments by Dennis Weber).

32 I do not mean to say that dividend stripping cannot be combated on the basis of Art. 1, para. 2; but probably the Member States will be free to make specific and proportionate/proportional anti-abuse provisions on the basis of Art. 1, para. 4

17 Oct. 1996, joined cases C-283/94, C-291/94 and C-292/94, Denkavit-VITIC-Voormeer, para. 31

34 For example, in a situation where a shareholding is increased just before dividend payment in order to comply with the PSD. According to Kok, in such a situation there is no longer a question of abuse under the OECD PPT rule: Q.W.J.C.H Kok, Enkele aspecten van de 'principle purpose test', WFR 2015/7083, p. 184.

35 Political agreement, Brussels 5 Dec. 2014, no. 16435/14. Adopted during the 3356th Council meeting, Council of the European Union, Brussels 9 Dec. 2014, no. 16603/ 14 , p. 20.

36 The Netherlands State Secretary of Finance made a remark of identical meaning: 'The current proposal for a general anti-abuse rule is a de minimis rule which means that i Member States have more stringent national anti-abuse provisions, these continue to apply in full. The background regarding this anti-abuse rule is to create an EU-wide equal lower limit to anti-abuse when applying the PSD'; see: Appendix 1, appreciation of anti-abuse provision in the Parent-Subsidiary Directive, pp 5 through 7 of letter 'Decision making on international files' ('Besluitvorming op international dossiers)' of 1 Dec. 2014, Ministry of Finance. 
The question is whether the observation that the Member States can still apply stricter national anti-abuse rules is in fact correct. It is indeed true that the new general anti-abuse provision intends to have the combating of abuse under the Parent-Subsidiary Directive on one line in all the Member States. In order to achieve this, a common description of what should be considered abuse is included in the Directive. The Member States are obliged to combat this abuse of the Parent-Subsidiary Directive. It is not so, however, that this means that the Member States have the discretion to also apply furtherreaching national anti-abuse measures. ${ }^{37}$ This cannot be derived either from the preamble or from the text of the directive. It would also be contrary to the objective of the common minimum provision, the precise objective of which is to combat abuse in all Member States, under the same conditions in the same manner and thereby, achieving consistency. In other words: the new general anti-abuse provision does not give carte blanche to the Member States to introduce anti-abuse provisions, which reach further than permitted by Article 1, paragraph 2. If that were so, then this would jeopardize the objective and purpose of the Parent-Subsidiary Directive, which exempts those dividends and other distributions of profit and endeavours to prevent double taxation. It cannot be so that due to a remark in the conclusions of the ECOFIN the purpose of the anti-abuse provision would be significantly extended: (i) contrary to the text of the provision itself; (ii) contrary to the objective of the amendment; and (iii) contrary to the objective and purpose of the directive as such. In the Denkavit-VITIC-Voormeer judgment, ${ }^{38}$ the Court had already ruled that expressions of intent made by the Member States in the Council, had no legal status 'if they are not actually expressed in the legislation. Legislation is addressed to those affected by it. They must, in accordance with the principle of legal certainty, be able to rely on what it contains'.

The new general anti-abuse provision, therefore, does not give carte blanche to the Member States to introduce anti-abuse provisions, which reach further than permitted by Article 1, paragraph 2 .

I note further that other anti-abuse provisions may still be possible on the basis of Article 1, paragraph 4 of the Directive, which provision allows non-mandatory anti-abuse provisions for the combating of tax evasion, tax fraud or abuse. What anti-abuse provisions this provision allows besides the general anti-abuse provision is unclear (see paragraph 3.3). Nevertheless, in my view, Article 1, paragraph 4 does not allow any further-reaching anti-abuse provisions when compared with the definition such as is included in Article 1, paragraph $2^{39}$. This is demonstrated explicitly from observations of the Presidency at the formation of this provision, who remarked that on the basis of Article 1, paragraph 4, domestic anti-abuse rules may be introduced 'that are less strict than the "minimum standard" proposed for inclusion in the revised PSD'. ${ }^{40}$ (Italics DW). Also, this provision does not give carte blanche to the Member States.

\section{IMPLEMENTATION OF THE AMENDMENT}

\section{I Implementation in Legislation or in National (Unwritten) Anti-abuse Doctrine}

It is not clear from the text of the amending directive whether an act of the legislature is actually obligatory in order to implement the general anti-abuse provision, or that, for example, it can suffice with the application of a general (unwritten) anti-abuse doctrine, which is based on the case law of the national court.

It follows from the case law of the $\mathrm{CJ}$ that in principle, no action of the legislature is obligatory at the implementation of a directive. There is no general principle that an implementation must always take place in legislation. The Member States, namely, are given the discretion by Article 288 TFEU to choose the form and methods whereby the result to be achieved by a directive can best be achieved. In the Kofoed case, ${ }^{41}$ the question was raised whether Denmark had implemented the (nonmandatory) general anti-abuse provision of Article 15 of the Merger Directive. The CJ did not require that the Danish legislature had included a provision in its legislation; a general principle on the basis of which abuse of law is prohibited could also suffice. 'Accordingly, provided that the legal situation arising from the national transposition measures is sufficiently precise and clear and that the persons concerned are put in a position to know the full extent of their rights and obligations, transposition of a directive into national law does not necessarily require legislative action in each Member State.', according to the CJ (see paragraph 44 from Kofoed).

Worthy of note, however, is that in Kofoed, it was the non-mandatory anti-abuse provision from the Merger Directive that was under dispute; in this case, there is a mandatory anti-abuse provision and besides, the purpose is

\section{Notes}

See also: F. Debelva \& J. Luts, The General Anti-Abuse Rule of the Parent-Subsidiary Directive 233 (IBFD ET 2015).

ECJ 17 Oct. 1996, joined cases C-283/94, C-291/94 and C-292/94, Denkavit-VITIC-Voormeer, para. 29.

Different: Q.W.J.C.H. Kok, De anti-misbruikbepaling in de moeder-dochterrichtlijn, MBB 2015/09.

See: Room document \# 1, Working party on Tax Questions - Direct Taxation, PSD - Anti-abuse rule, 24 Jul. 2014, p. 4, published in: Highlights \& Insights on European Taxation, H\&I 2015/274 (comments by Dennis Weber).

41 CJ 5 Jul. 2007, case C-321/05, Kofoed. 
to achieve a more consistent application of the combating of abuse in the various Member States. The question is whether the non-inclusion in legislation of the new general anti-abuse provision is in fact in accordance with this striving for consistency and with the principle of legal certainty. I doubt whether a mere reference to a national anti-abuse principle based on case law could offer this consistency and legal certainty, because it not immediately clear whether this case law is in accordance with Article 1, paragraph 2 of the directive or whether the national court would be prepared to explain the national principle in accordance with the general anti-abuse provision. ${ }^{42}$ The inclusion in legislation of the general anti-abuse provision would seem the most appropriate means of ensuring the effectiveness of the directive. ${ }^{43}$ For that matter, it was also assumed in the Impact Assessment to the November 2013 proposal that the amendment would be included in legislation. In the Impact Assessment, the fact was dealt with that Member States have a variety of different antiabuse provisions and as example, mentioned Denmark, which does not have a general anti-abuse provision in legislation but only uses case law on the basis of which abuse can be combated. The purpose of the amending directive is to achieve consistency here and that would seem to mean that all the Member States will have to incorporate the new anti-abuse provision in legislation. ${ }^{44}$

\subsection{Impact on Bilateral Tax Treaties Concluded between EU Member States}

A question that arises is whether the Member States must also include the common minimum abuse rule in bilateral tax treaties concluded between the Member States. The directive itself makes no mention of being included in national or bilateral law, although in the impact assessment of the November 2013 proposal, mention is made of 'domestic legislation' 45 and also in the Room Documents of the Italian Presidency, no mention of implementation in bilateral treaties is to be found, reference is only made to 'domestic provisions' ${ }^{46}$

The question is important, for example, in a situation in which a Member State levies a withholding tax of $25 \%$ on paid dividend which, in situations that fall under the PSD, is reduced to $0 \%$ (exemption from dividend tax). Assume that in a certain situation at payment of dividend there is abuse within the meaning of Article 1, paragraph 2 PSD and that this Member State had implemented this provision in its national legislation. This Member State must then refuse the benefits of the directive and thus, not grant any exemption from withholding tax on the basis of its national law. But may the Member State subsequently reduce the withholding tax on dividend to $0 \%$ in a bilateral tax treaty concluded with the other Member State? I am of the opinion that if that can be done, it would detract from the effectiveness of the common minimum anti-abuse rule. The object of the common minimum anti-abuse rule, to wit, is setting an equal (the preamble mentions 'common' and 'consistency') minimum standard on the combating of abuse, can then be undermined in a bilateral tax treaty. ${ }^{47}$ This is endorsed by Article 4(3) EU Treaty (the principle of sincere cooperation), which provision determines that the Member States shall take any appropriate measure, in general or particular, to ensure fulfilment of the obligations arising out of the Treaties' and that 'The Member States shall facilitate the achievement of the Union's tasks and refrain from any measure which could jeopardize the attainment of the Union's objectives'. When by means of a tax treaty a tax advantage is still given then, in my view, the principle of sincere cooperation is not satisfied.

Debelva and Luts argue ${ }^{48}$ that because Article 1, paragraph 2 determines that 'Member States shall not grant the benefits of this Directive', only PSD benefits may be denied and not those that stem from other legal sources (such as tax treaties). I cannot agree with this. An exemption from withholding tax such as laid down in a tax treaty can namely just as well be regarded as a 'benefit', which is granted by the PSD. A directive, namely, is only binding as concerns the result to be achieved and the Member States not only can lay down the exemption from the PSD in national legislation, but also can include it in bilateral treaties. ${ }^{49}$

On the basis of a literal and theological interpretation, I thus come to the conclusion that Article 1, paragraph 2 must also extend to bilateral tax treaties.

\section{Notes}

42 Due to this, for example, a difference would arise between the interpretation of the national principle in various situations (for example, between situations where the Parent-Subsidiary Directive is and is not applicable).

43 See CJ 8 Apr. 1976, case C-48/75, Royer, paras 73 and 75.

44 Commission staff working document, Impact Assessment, 25 Nov. 2013, SWD (2013) 474 final.

45 Commission staff working document, Impact Assessment, 25 Nov. 2013, SWD (2013) 474 final.

46 See for instance: Room document \# 3, Working party on Tax Questions - Direct Taxation, PSD - Anti-abuse rule, 17 Sep. 2014, p. 3, published in: Highlights \& Insights on European Taxation, H\&I 2015/275 (comments by Dennis Weber).

See also: O.C.R. Marres \& I.M. de Groot, De algemene antimisbruikbepaling in de moeder-dochterrichtlijn (deel 2), WFR 2015/7107, p. 915.

48 F. Debelva \& J. Luts, The General Anti-Abuse Rule of the Parent-Subsidiary Directive para. 3.3.2 (IBFD ET 2015). See for the same view also: Q.W.J.C.H. Kok, De antimisbruikbepaling in de moeder-dochterrichtlijn, MBB 2015/09.

49 In theory, a Member State can include a withholding tax on dividend in its national legislation and include in its bilateral treaties with all Member States an exemption from dividend tax when the conditions of the PSD have been fulfilled. 
For the sake of completeness, I also note that Article 7, paragraph 2 of the directive does not detract from this. This provision determines: 'This directive shall not affect the application of domestic or agreement-based provisions designed to eliminate or lessen economic double taxation of dividends, in particular provisions relating to the payment of tax credits to the recipients of dividends'. Debelva and Luts suggest that on the basis of this provision, Article 1, paragraph 2 does not extend to bilateral treaties. ${ }^{50}$ This, however, is based on, in my view, wrong reading of Article 7, paragraph 2: First, Article 7, paragraph 2 is not limited to bilateral treaties ('agreement-based provisions'), but is also applicable in case of 'domestic provisions'. When Article 7, paragraph 2 would thus be of importance, then Article 1, paragraph 2 would also not extend to all domestic provisions designed to eliminate or lessen economic double taxation of dividends. This would render Article 1, paragraph 2 a hollow phrase. I doubt that is the intention of the directive amendment. Besides, Article 7, paragraph 2 only provides for the prevention of economic double taxation, thus only for the benefits of Article 4 (not for juridical double taxation such as exemption from withholding tax on dividend). The reason for including Article 7, paragraph 2 was to ensure that the Member States might also take other measures for the prevention of economic double taxation, particularly the granting of a tax credit under an imputation system. ${ }^{51}$ It is in this context that Article 7, paragraph 2 must be explained. ${ }^{52}$

\subsection{Concrete Implementation in Tax Treaties, the Limits of EU Consistent Interpretation and the Prohibition of Inverse Direct Effect}

That the common anti-abuse rule extends to tax treaties does not have to mean that Article 1 (2) must always be incorporated in tax treaties. Because as a rule, the Member States will include Article 1, paragraph 2 in their national legislation and the consequence of the common anti-abuse rule in my view must be that the artificial arrangement must be ignored $^{53}$, and therefore, the result must be that in the end the relevant tax treaty will no longer be applicable. ${ }^{54}$ In this regard, an important question is how the Member States will precisely give form to the impact of the common anti-abuse rule under tax treaties. This can be done, for example, by including a similar provision in bilateral tax treaties with EU Member States or because the national anti-abuse provision sets the tax treaty aside (treaty override). But imagine, that a certain Member State does not implement the common anti-abuse rule explicitly in a tax treaty and the national law of the Member States also does not override the tax treaty with a clear national provision; the only method left for the Member State is that the national court, on the basis of an interpretation in conformity with the directive declares the tax treaty not applicable to an abusive arrangement. Under Article 4(3) EU Treaty (the principle of sincere cooperation), a national court must interpret national law, to the extent possible, in the light of the wording and the purpose of EU law (this is also called: 'EU consistent interpretation'; compare also the Marleasing-case ${ }^{55}$ ). Under this case law, to the extent permitted by national law, the national court must attempt to interpret national law in such a way as to avoid conflict with EU law. The national courts must interpret national law in conformity with EU law 'for matters within their jurisdiction' and thus do not have to act as legislators. Moreover, the judicial duty of giving an interpretation that is in conformity with EU law is limited by general legal principles such as the principle of legal certainty. An interpretation that is in conformity with EU law may, according to the case law, not lead to the inverse direct effect of EU law. ${ }^{56}$ The prohibition of inverse direct effect means that a Member State (read: the tax administration) may not invoke a directive that is disadvantageous to an individual if it has not (yet) been implemented or that has been incorrectly implemented. The idea is that a government is not allowed to profit from its own negligence (also known as the estoppel principle). The leading case disallowing inverse direct effect is Kolpinghuis Nijmegen. ${ }^{57}$ Since then, the Court has recalled

\section{Notes}

See: F. Debelva \& J. Luts, The General Anti-Abuse Rule of the Parent-Subsidiary Directive para. 3.3.2 (IBFD ET 2015).

See B.M. Terra \& P.J. Wattel, European Tax Law 641 (Deventer, Kluwer, 2012).

See also O.C.R. Marres \& I.M. de Groot, De algemene antimisbruikbepaling in de moeder-dochterrichtlijn (deel 2), WFR 2015/7107, p. 915.

In order to avoid repetition, I will discuss the consequences of abuse further in para. 8.3.

Different: Debelva and Luts; in their example, they assume that the relevant tax treaty is still applicable. See: F. Debelva \& J. Luts, The General Anti-Abuse Rule of the ParentSubsidiary Directive para. 3.3.2 (IBFD ET 2015).

55 CJ 13 Nov. 1990, case C-106/89 (Marleasing), ECR I-4135.

56 See in this regard with regard to criminal law: CJ 26 Sep. 1996, case C-168/95 (Arcaro), ECR I-4705, para. 42. The limits of an interpretation in conformity with EU law in this case lie '(...) where such an interpretation leads to the imposition on an individual of an obligation laid down by a directive which has not been transposed or, more especially, where it has the effect of determining or aggravating, on the basis of the directive and in the absence of a law enacted for its implementation, the liability in criminal law of persons who act in contravention of that directive's provisions'.

57 ECJ 8 Oct. 1987, case 80/86 (Kolpinghuis Nijmegen), ECR p. 3969. 
the prohibition of inverse direct effect in tax law decisions such as Kofoed ${ }^{58}$ on the Merger Directive. ${ }^{59}$

In short, if the anti-abuse rule is only implemented in national law and not explicitly in a tax treaty and the national law also does not contain a clear provision whereby the tax treaty is set aside, a national court must examine whether in the case of an abusive arrangement, on the basis of interpretation of the bilateral treaty, it can include the common anti-abuse rule in the tax treaty (by declaring the tax treaty not applicable). It must, however, remain within its 'jurisdiction' and the interpretation may not lead to inverse direct effect.

If we take the Netherlands as an example, we see that the Netherlands has included in the tax treaty with some EU Member States, a main purpose test in the dividend article (for instance, with the United Kingdom and Malta $\left.{ }^{60}\right)$. The main purpose test in those treaties is different (and more limited) from the main purpose test of the common anti-abuse rule of the PSD, but it cannot be ruled out that a national court will, by way of interpretation, read the main purpose test of PSD into the main purpose test of the tax treaty. Of importance in that framework is that the Netherlands Supreme Court has imposed on the national courts a broad obligation of EU consistent interpretation ${ }^{61}$.

In the case the Netherlands has not implemented the common anti-abuse rule in its tax treaties and also the relevant tax treaty has not a main purpose test such as that in the tax treaties with the United Kingdom and Malta, it important that on the basis of Article 94 of the Netherlands Constitution, bilateral tax treaties prevail over the national law. That is why I am of the view that it would be difficult for a Netherlands court, other that reading into the text of the bilateral treaty by way of interpretation, to set aside a bilateral treaty. In that case, a national court would in fact be in violation of Article 94 of the Constitution. Setting the Constitution aside by invoking the direct effect of the common anti-abuse rule can only be done by the taxpayer and not by the tax administration, due to the prohibition on inverse direct effect. $^{62}$ It is, however, the tax administration, which would invoke the non-applicability of the tax treaty to remove the abusive arrangement. In the light of the prohibition on inverse direct effect, this would not seem possible. One solution to this problem could be an amendment of all the Netherlands bilateral tax treaties with EU Member States. Another could be applicability of the Principle purpose test such as was proposed by the OECD in action 6, which could enter into force by means of the multilateral instrument, such as is now under discussion in the framework of the OECD BEPS action $15^{63}$.

Be that as it may, until the Netherlands has implemented such a solution, it is highly debatable whether the Netherlands can duly extend application of the common anti-abuse rule to bilateral treaties if which they have not already included a main purpose test. It would seem that a taxpayer, also in the case of an abusive arrangement under the common anti-abuse rule, can still invoke the applicable tax treaty and on that basis can, for example, enforce a lower withholding tax.

\subsection{Other Description of Abuse Allowed?}

Another question is whether the Member States are permitted to include a different description of abuse in their legislation than that described in Article 1, paragraph 2. In light of the purpose of the amendment, namely, 'consistency', and the fact that application of the general abuse provision entails a tax levy (thus costs) it is defendable that the general anti-abuse provision, 'be clear and precise so that he [read taxpayer] may be able to ascertain unequivocally what his rights and obligations are and take steps accordingly'. 64 On the basis of this reasoning, a deviating description would not seem to be permitted. In the room-documents regarding the common anti-abuse rule, however, the Presidency made observations in another direction. It was observed: if a Member States already has a domestic anti-abuse provision which is at least as strict as the proposed minimum standard, no further action is required by that Member

\section{Notes}

ECJ 5 Jul. 2007, case C-321/05 (Kofoed)

59 At issue in this case was, among other things, whether or not Denmark had included an anti-avoidance provision in its legislation implementing the anti-avoidance provision of Art. 11(1) (a) of the Merger Directive. If there was no national anti-avoidance provision in the Danish legislation, the Danish tax authorities could not rely directly on the anti-avoidance provision of the Merger Directive in order to combat abuse since this would amount to inverse direct effect, according to the CJ. It was then up to the national court to determine whether Denmark had implemented such an anti-avoidance provision in its legislation.

60 But also with the Republic of Latvia and Romenia. See about the main-purpose test in the Netherlands tax treaties: B.R. Zoetmulder en R.J.M. de Klijn, De main purposetest in Nederlandse verdragen en buitenlands AB: een aanbeveling, NTFRA2013-20.

61 The Netherlands Supreme Court, namely, is of the opinion that where the wording of the national law so permits, national law must always be interpreted in accordance with EU law. This is thus a very broad EU consistent interpretation obligation. This would only be otherwise - and, according to the case law of the Netherlands Supreme Court, would be in conflict with the principle of legal certainty - in the event such national explanations or expressions unambiguously express the deliberate intention to have the national regulation derogate from that which is mandatory under the directive; see: HR 10 Aug. 2007, BNB 2007/277 (comments by Bijl).

62 That directly applicable EU law can also set aside a provision laid down in a Constitution; see: Simmenthal, 106/77, para. 22 and more recently: 4 Jun. 2015, C-5/14, Kernkraftwerke Lippe-Ems, para. 33.

63 See: Developing a multilateral instrument to modify bilateral tax treaties, Action 15: 2015 Final report, OECD/G20 Base Erosion and Profit Shifting project.

64 See by analogy: CJ 13 Feb. 1996, C-143/93, Van Es. 
State to implement the anti-abuse rule in the PSD. If a Member State does not have any domestic anti-abuse provision or has an anti-abuse provision which is less strict than the proposed de minimis rule, only in these circumstances a Member State would need to transpose in its domestic law the anti-abuse provision included the PSD'. It would appear to follow from these observations that it is sufficient that the result of the common minimum anti-abuse provision is achieved and that it is not required that this be incorporated literally. We can, namely, assume that already existing legislation will never use the same wording as the new provision. The question then is also how to test whether a provision which combats that abuse with other conditions, combats the same minimum abuse as that combated in Article 1, paragraph 2 .

In practice, it can be expected that Member States, particularly for the applicability of the dividend withholding tax exemption, will set certain substance criteria on the parent company receiving the dividend in order to substantiate the not genuine/economic reality-test (see further on this test paragraph 6.4. and 7). I wish to note in general that the main rule remains, if the PSD is applicable, a dividend withholding tax exemption must be granted. When the Member States make this exemption dependent on certain substance requirements (substantiating the not genuine/economic reality test), then this would form a general anti-abuse criterion, which does not take into account the situation of individual cases and, according to case law such as Leur-Bloem, this is not permitted. ${ }^{65}$

\subsection{Anti-abuse Provision Must Be Implemented Both for the Dividend Withholding Tax and for the Participation Exemption/Credit Method}

Article 1, paragraph 2 is applicable for all the benefits, which are granted by the Parent-Subsidiary Directive. The mandatory application, therefore, is not limited to the benefit that Article 5 offers (exemption of dividend tax), the benefits on the basis of Article 4 (prevention of economic double taxation) also fall under the scope of application. In appendix III to the political agreement ${ }^{66}$ such as was adopted during the ECOFIN of 9 December 2014, however, the following Statement of the Commission is included: "The Commission confirms that the proposed amendments to Article 1, paragraph 2 of the Parent Subsidiary directive are not intended to affect national participation exemption systems in so far as these are compatible with the Treaty provisions'. It is not clear what the reason for this Statement is, or what its legal value is. It would appear to me that this statement cannot remove the mandatory effect of the anti-abuse provision. To me, the legal effect would appear to be lacking, given that the Statement does not appear in the text of the directive itself and not in the preamble. ${ }^{67}$

The Member States, therefore, will also have to implement Article 1, paragraph 2 in situations in which Article 4 of the directive is applicable (which provides for a choice between a participation exemption and a credit system). 68

The Statement of the Commission would seem to endorse that Article 1, paragraph 2 particularly provides for abuse of the withholding tax exemption. The problem, however, is that it is not demonstrated either from the text of the anti-abuse rule or from the preamble that Article 1, paragraph 2 is limited to such like abuse. The text is so broad that many other abuse situations can also fall under it (see further paragraph 7.1.).

Be that as it may, in the light of the Statement of the European Commission, it would seem that the Commission will not insist in such like situations, that the Member States also implement Article 1, paragraph 2. We can wonder why this has not been expressed clearly in the text of the provision itself.

Whereas, I would point out an example given by the Commission in 'the questions and answers on tax transparency' memo published further to the tax transparency package on 18 March 2015.69 As regards abuse of the participation exemption, this example seems to point in another direction:

Member State $\mathrm{X}$ is a low tax country. A company in Member State $\mathrm{X}$ gets a tax ruling from the authorities there, confirming that it can charge very high prices for goods sold to its parent company in Member State Y.

Notes

65 Leur-Bloem, C-28/95, para. 44.

66 Political Agreement, Brussels 5 Dec. 2014, no. 16435/14. Adopted during the 3356th Council meeting, Council of the European Union, Brussels 9 Dec. 2014, no. 16603/ 14, p. 20.

67 See: ECJ 17 Oct. 1996, joined cases C-283/94, C-291/94 and C-292/94, Denkavit-VITIC-Voormeer, para. 29.

68 Otherwise; O.C.R. Marres and I.M. de Groot, De algemene antimisbruikbepaling in de moeder-dochterrichtlijn (deel 2), WFR 2015/7107, p. 915, who argue that the directive is only aimed at directive shopping in order to evade withholding tax on dividend and therefore only the exemption from dividend tax (Art. 5) has to be denied. In my view, the scope of the anti-abuse rule, however, is broader than only directive shopping to evade withholding tax. See further s. 7.1.

69 Questions and answers on tax transparency, 18 Mar. 2015, MEMO/15/4609. 
By doing this, the company generates artificially high profits in Member State X, which are taxed at a low rate.

The same company then transfers those profits back to the parent company in Member State $\mathrm{Y}$ in the form of dividends. By doing this, it avoids any further taxes on those profits, in line with the EU Parent-Subsidiary Directive. This Directive gives a tax exemption to dividends transferred between a subsidiary and its parent company, in an effort to prevent the double taxation of companies.

With the automatic exchange of information, Member State $\mathrm{Y}$ would find out about the artificially high prices that the subsidiary is charging to the parent company, in order to shift profits to Member State X. As a result, it may be able to apply the anti-abuse element of the Parent-Subsidiary Directive, and deny the company the usual tax exemption for dividends.

In this example, we see that the Commission suggests denial of the participation exemption under the ParentSubsidiary Directive. The wording 'may be able' could point to application of the non-mandatory anti-abuse provision in Article 1, paragraph 4 of the directive, but it is certainly not clear. It could also be that the Commission had the general anti-abuse provision of Article 1, paragraph 2 in mind and with 'may be able' refers to the circumstance that Member State $\mathrm{Y}$ is informed of the ruling of Member State $\mathrm{X}$ due to the exchange of information and therefore, 'may be able' to apply Article 1 , paragraph 2 of the directive ${ }^{70}$. If this so, then this is counter to the Statement of the Commission in the political agreement specified here above.

\section{The three tests}

The general anti-abuse provision contains three tests that must be satisfied in order to come to the conclusion that abuse is present:

- Main purpose test.

- Conflict with object and purpose test.

- Not genuine (artificiality)/economic reality test.

\section{I General:The Relation to the Principle Purpose Test (PPT) in OECD Action Plan 6}

During the formation of the directive, the Presidency observed that the 'main purpose test' goes in the direction followed by the OECD in its parallel work on BEPS' (...) 'as regards entitlement to tax benefits' ${ }^{71}$ Here reference is made to 'BEPS Action 6: Preventing the granting of treaty benefits in inappropriate circumstances', ${ }^{72}$ in which, amongst others, it is proposed to apply a principle purpose test rule (PPT) for the combating of treaty shopping.

Indeed it can be established that the common antiabuse rule from the PSD and the OECD PPT show similarities and that thus probably inspiration can be drawn from the various examples, which are given in the OECD Action 6 report when there is or is not a matter of treaty abuse within the meaning of the OECD PPT. The CJ has previously, under the treaty freedoms, been open to take into account the interpretation of EU law provisions in (and the comments to) the OECD Model Treaty. In the Van Hilten case, the CJ ruled 'for the purposes of the allocation of powers of taxation, it is not unreasonable for the Member States to find inspiration in international practice and, particularly, the model conventions drawn up by the Organisation for Economic Cooperation and Development (OECD)'. ${ }^{73}$

As said, on the one hand, there are clear similarities between the OECD PPT and the anti-abuse rule from the PSD (namely also a subjective test and an objective test), but, on the other, in the OECD PPT the not genuine/ economic reality test is not explicitly included. ${ }^{74}$ Yet an economic reality test would also seem to form part of the OECD PPT. First, in the (final) report regarding BEPS Action 6, as general objective of tax conventions it is pointed out that these "provide benefits in respect of bona fide exchanges of goods and services, and movements of capital and persons" and to "encourage cross-border investment' ${ }^{75}$ this comes close to the objective of the Parent-Subsidiary Directive, to wit, to eliminate disadvantage to cooperation between companies between different Member States' (see further paragraph 6.3). Moreover, as an example that the OECD PPT is not applicable, in BEPS Action 6 reference is made to the

\section{Notes}

70 For that matter, the problem, which is addressed in the example is a profit allocation on the basis of (wrong application of) transfer-pricing rules and the non-application of the participation exemption would seem to be an unsuitable instrument. In my view, this problem would be solved by using the correct transfer price in Member State Y.

71 Room document \# 3, Working party on Tax Questions - Direct Taxation, PSD - Anti-abuse rule, 17 Sep. 2014, p. 2 and 5, published in: Highlights \& Insights on European Taxation, H\&I 2015/275 (comments by Dennis Weber)

72 This started with the public discussion draft 'BEPS Action 6: Preventing the granting of treaty benefits in inappropriate circumstances, 14 Mar. 2014 , OECD and ended with the final report published on the 5 th of October 2015

CJ 23 Feb. 2006, C-513/03, Van Hilten, para. 48. See also CJ 12 May 1998, C-336/96, Gilly, para. 31

74 The European Commission is of the opinion that the OECD principle purpose test is only in accordance with EU law if a 'genuine economic activity' test is added to the provision; see: European Commission, Working document, Brussels 10 Sep. 2014, Taxud D3, Working party IV - Direct taxation, OECD BEPS Action 6 draft: Limitation on Benefits' provisions - interaction with EU law, p. 10.

75 See: Preventing the granting of treaty benefits in inappropriate circumstances, Action 6: final report, OECD/G20 Base Erosion and Profit Shifting project, 5 Oct. 2015, commentary on the PPT rule: point 6 and point 14, example C. 
situation that a certain shareholding in a company is 'related to the expansion' of the shareholders 'business and lower manufacturing costs'. ${ }^{76}$ In another example, the OECD PPT is not applicable because there is the establishment of a regional group services company, which has a 'real business', whereby the service company 'exercises substantive economic functions, using real assets and assuming real risk' and that the business is carried on by the company 'through its own personnel'. ${ }^{77}$ There is in Action 6 also a reference to 'valid commercial reasons' ${ }^{78}$ It can be derived from this that the not genuine/economic reality test is also to be found under the OECD PPT ${ }^{79}$ and that inspiration can probably be drawn from this.

\subsection{Main Purpose Test (Subjective Test)}

The main purpose test of Article 1, paragraph 2 of the anti-abuse rule determines that there must be an 'arrangement or a series of arrangements which, having been put into place for the main purpose or one of the main purposes of obtaining a tax advantage'.

\subsection{Main Purpose}

During the formation of the common minimum antiabuse rule, a proposal was made to define the term 'main purpose'. This proposal, however, was never adopted. This (never adopted) text reads: ${ }^{80}$ 'For the purposes of paragraph 2, a given purpose shall be considered to be the main purpose where other actual purposes that are or could be attributed to the arrangement or series of arrangements appear to be secondary in view of all the facts and circumstances of the case'. This proposal thus differentiates between main and secondary purposes. In the commentary to the OECD PPT of Action 6, the term principle purpose is described as follows: 'A purpose will not be a principal purpose when it is reasonable to conclude, having regard to all relevant facts and circumstances, that obtaining the benefit was not a principal consideration and would not have justified entering into any arrangement or transaction that has, alone or together with other transactions, resulted in the benefit. In particular, where an arrangement is inextricably linked to a core commercial activity, and its form has not been driven by considerations of obtaining a benefit, it is unlikely that its principal purpose will be considered to be to obtain that benefit' ${ }^{\prime 1}$. Here the OECD would also seem to point out that the tax benefits, which are obtained in a certain transaction could be more of a secondary nature (or an accessory) of the commercial activity. This, under the condition that the arrangement and the core commercial activity are 'inextricably linked'. Here we see a parallel with the description 'other actual purposes' 'could be attributed to the arrangement' such as the proposal, which was not adopted under the PSD. One of the examples given in the comments to the OECD PPT in which the principle purpose was not to obtain a tax benefit, is the example of the acquisition of a family-owned holding company which acquisition was 'related to the expansion of the business' of the shareholder. ${ }^{82}$ The fact that the family-owned holding was established in a country, which had concluded many tax treaties providing for no or low source taxation on dividends and royalties can then be regarded as a secondary purpose or tax favourable accessory.

\subsubsection{Main Purpose versus 'Wholly Artificial'}

The terminology 'main purpose or one of the main purposes' is broader than the 'wholly artificial arrangements', which the $\mathrm{CJ}$ requires if there it to be a matter of abuse under the Treaty freedoms. ${ }^{83}$ The Presidency observed that the "proposed definition is broadly in line with the case-law of the CJEU as regards abuse and goes in the direction followed by the OECD in

\section{Notes}

76 Preventing the granting of treaty benefits in inappropriate circumstances, Action 6: final report, OECD/G20 Base Erosion and Profit Shifting project, 5 Oct. 2015, commentary on the PPT rule: point 14, example C (manufacturing plant in developing country).

77 Preventing the granting of treaty benefits in inappropriate circumstances, Action 6: final report, OECD/G20 Base Erosion and Profit Shifting project, 5 Oct. 2015, commentary on the PPT rule: point 14 , example G.

78 Preventing the granting of treaty benefits in inappropriate circumstances, Action 6: final report, OECD/G20 Base Erosion and Profit Shifting project, 5 Oct. 2015, commentary on the PPT rule: point 8.

79 Marres and De Groot read in the OECD PPT a not genuine/economic reality test and come to the conclusion that the OECD and the anti-abuse rule in de PSD do not differ essentially from each other on that point. See: O.C.R. Marres and I.M. de Groot, De algemene antimisbruikbepaling in de moeder-dochterrichtlijn (deel 1), WFR 2015/ 7107 , p. 911

80 See: Room document \# 3, Working party on Tax Questions - Direct Taxation, PSD - Anti-abuse rule, 17 Sep. 2014 , p. 4 and the annex, published in: Highlights \& Insights on European Taxation, H\&I 2015/275 (comments by Dennis Weber).

81 Preventing the granting of treaty benefits in inappropriate circumstances, Action 6: final report, OECD/G20 Base Erosion and Profit Shifting project, 5 Oct. 2015, commentary on the PPT rule: point 13.

82 Preventing the granting of treaty benefits in inappropriate circumstances, Action 6: final report, OECD/G20 Base Erosion and Profit Shifting project, 5 Oct. 2015, commentary on the PPT rule: point 14, example F.

83 See for instance: 12 Sep. 2006, case C-196/04, Cadbury Schweppes, para. 51. 
parallel work on BEPS as regards entitlement to tax benefits' ${ }^{84}$

In literature, the reaction is mainly to reject a main purpose test; for example, De Broe and Luts ${ }^{85}$ (in the framework of the OECD PPT) and Debelva and Luts ${ }^{86}$ (in the framework of the EU anti-abuse rule) are of the opinion that main purpose test is 'fundamentally inacceptable' because due to this, a taxpayer can no longer rely on the granting of tax benefits when making business decisions. They are of the opinion that the main purpose test will have to be interpreted as a sole or predominant test. Szudoczky is of the opinion that a main purpose test (which she discusses in the framework of the merger directive) itself can be in conflict with primary EU law. ${ }^{87}$

I concede that the 'main purpose' test clearly deviates in text from the 'wholly artificial' test from the case law of the $\mathrm{CJ},{ }^{88}$ nevertheless, the question is whether in practice, the difference between the two tests is so great. if there is to be a matter of a wholly artificial arrangement under the Treaty freedoms, then there must be, namely; (i) a tax advantage; 89 (ii) conflict with the object of the treaty freedoms; 90 (iii) the intention of the taxpayer must be to obtain a tax advantage; 91 and (iv) the arrangement must be 'artificial'. 92

The wholly artificial arrangement test would appear to be stricter in the sense that it would seem to follow from this that where a taxpayer also has another intention for a certain arrangement (for example, a business intention) there is no question of a wholly artificial arrangement; whereas under the main purpose test, having another reason still places a taxpayer under the common anti-abuse rule. Nevertheless, the question here is if there really is a difference. It must be pointed out, namely, that under the case law of the CJ, when an arrangement forms an artificial arrangement 'in whole or in part', there can be a matter of abuse. ${ }^{93}$ It would appear to follow from this that the existence of a business reason for one part of a transaction does not remove the abuse intention for the other part. Part of the transaction (a certain step) can also be 'wholly artificial'. In other words: there can also be a matter of abuse under the wholly artificial arrangement test when in addition there are also non-fiscal reasons (for another part of the transaction). That is the same as under the main purpose test.

\subsection{3 'Main' versus 'Predominant'}

In the Foggia case ${ }^{94}$, the CJ interpreted the principle objective test in the Merger Directive such (in conflict with the literal text), that there is abuse when tax considerations are 'predominant'. Szudoczky has (rightly so) harsh criticism of this interpretation of the CJ because it is in conflict with the literal text of the anti-abuse provision of the Merger Directive. ${ }^{95}$ But whatever the case, in the light of the fact that the principle objective test from the Merger Directive and the main purpose test in the Parent-Subsidiary Directive are comparable ${ }^{96}$, it cannot be excluded that the CJ will also follow a similar interpretation under the main purpose test in the Parent-Subsidiary Directive.

\subsubsection{Tax Advantage}

The main purpose(s) must be to obtain a 'tax advantage'. There must thus be an advantage as compared to another

\section{Notes}

84 See: Room document \# 3, Working party on Tax Questions - Direct Taxation, PSD - Anti-abuse rule, 17 Sep. 2014, p. 5, published in: Highlights \& Insights on European Taxation, H\&I 2015/275 (comments by Dennis Weber).

85 L. de Broe \& J. Luts, BEPS Action 6: Tax Treaty Abuse, Intertax 132 (2015).

86 F. Debelva \& J. Luts, The General Anti-Abuse rule of the Parent-Subsidiary Directive 225 (IBFD ET 2015).

87 R. Szudoczky, The Sources of EU Law and Their Relationships: Lessons for the Field of Taxation 424 (IBFD 2014). In which she criticizes the fact that the CJ interprets the main purpose test in the Merger Directive such that this is in line with the other abuse case law of the CJ. See also: E.C.C.M Kemmeren, Where Is EU Law in the OECD BEPS Discussion?, 4 EC Tax Rev. 190 (2014).

88 See also: A. Dourado, Aggressive Tax Planning in EU Law and in the Light of BEPS: The EC Recommendation on Aggressive Tax Planning and BEPS Actions 2 and 6, 1 Intertax 56 (2015).

89 See: 12 Sep. 2006, C-196/04, Cadbury Schweppes, para. 55: 'with a view to escape the tax normally due on the profits generated by activities carried out on national territory'.

9012 Sep. 2006, C-196/04, Cadbury Schweppes, para. 52

912 Sep. 2006, C-196/04, Cadbury Schweppes, para. 64.

92 Dennis Weber, Abuse of Law in European Tax Law: An Overview and Some Recent Trends in the Direct and Indirect Tax Case Law of the ECJ, 6 European Taxation 253 (2013) (part 1).

93 See: 13 Mar. 2007, case C-524/04, Thin Cap GLO, para. 81

9410 Nov. 2011, case C-126/10, Foggia, para. 35.

95 See: R. Szudoczky, The Sources of EU Law and Their Relationships: Lessons for the Field of Taxation 424 (IBFD 2014).

96 That it has to concern the 'main purpose or one of the main purposes of obtaining a tax advantage' in the new anti-abuse rule in the PSD is comparable to the anti-abuse provision of Art. 15 of the Merger Directive, which determine 'its principal objective or as one of its principal objectives'. Art. 15 of the Merger Directive, however mentions that the principle objective must be 'tax evasion or avoidance' instead of a 'tax advantage' such as in the new anti-abuse provision in the PSD. So there is a difference in the wording. In the end, although I am of the view that there is little difference because ultimately under the new anti-abuse provision, it will have to be established whether a arrangement as main purpose (or one of the main purposes) is the obtaining of a tax advantage, which constitutes abuse (namely, in conflict with the object and purpose of the directive and is artificial). 
situation. ${ }^{97}$ Assume, for example, that a company established in EU Member State $S$ pays a dividend to its parent company established in non-EU State P. In EU Member State S, a dividend withholding tax is levied of $25 \%$, which is reduced to $0 \%$ by the bilateral tax treaty concluded between EU Member State S and State P. Assume that a subholding is interposed between the parent company and the subsidiary, which is established in EU Member State SH. When a dividend is now paid by the subsidiary $\mathrm{S}$ to its subholding established in EU Member State SH, then the PSD will be applicable to this and EU Member State $S$ has to grant an exemption from the dividend withholding $\operatorname{tax} \operatorname{van} 25 \%$. In this situation, due to the arrangement (the interposing of the subholding) use is made of a benefit of the PSD (the exemption), but this does not lead to a tax advantage. Without the interposing, namely, there would not have been a levy of dividend withholding tax (due to application of the tax treaty). In a case like this, the common anti-abuse rule is in my view not applicable.

In addition, there must be a 'tax advantage' which, in my view, arises from making use of the benefits of the PSD. If there is no tax advantage by making use of the PSD (for example, because use had already been made of the benefits of the PSD prior to the arrangement) but, due to a certain arrangement, use can be made of another tax advantage (for example, because a tax treaty with lower levies at source on interest payments is applicable), then in my view, there can be no question of a 'tax advantage that defeats the object or purpose of the directive'. Assume, for example, that there is an EU Group: Holding $\mathrm{X}$ holds $100 \%$ of the shares in Company $\mathrm{A}$, which in turn holds $100 \%$ of the shares in company $\mathrm{B}$. The companies are established in different EU Member States. The PSD is applicable to the shareholding of Holding $\mathrm{X}$ in company $\mathrm{A}$ and to the shareholding of company A in company B. Assume that the seat of company A is relocated to another EU Member State because that Member State has a tax treaty (with the Member State in which company B is established) with lower rates of source tax on interest payments. The tax advantage of the arrangement (relocating seat of company A) is thus a lower rate of source tax on interest in the Member State in which company $\mathrm{B}$ is established. Relocating the seat does not lead to tax advantages, which arise from the PSD. The benefits of the PSD were also enjoyed prior to the relocation of seat.

That such a tax advantage does not fall under the common anti-abuse rule is also apparent from the judgment in the Zwijnenburg case, ${ }^{98}$ which was ruled on the common anti-abuse provision of the Merger Directive. The question in this case was whether the benefits of the Merger Directive may be withheld from a taxpayer because he had set up an arrangement to avoid the Netherlands transaction tax. The Netherlands transaction tax, however, is not a tax, which is covered by the Merger Directive. The Court ruled that the anti-abuse provision was only applicable to the taxes expressly referred to in the Merger Directive and could not be applied when other taxes would be avoided through a merger. I am of the view that the same reasoning can also be applied in the example above. A levy at source on interest could probably, in certain circumstances, be qualified as an advance levy on corporate taxation (a tax which does fall under the PSD), but it fails to be seen that the avoidance of a levy at source on interest would be in conflict with the object or purpose of the PSD.

\subsubsection{Arrangement}

The term 'arrangement' must, according to the Room documents, be interpreted in accordance with the Recommendation on aggressive tax planning, ${ }^{99}$ which contains 'any transaction, scheme, action, operation, agreement, grant, understanding, promise, undertaking or event'. 100

The wording of the provision used whereby it must concern an arrangement 'having been put into place for' would seem to imply that arrangements that had been set up prior to 1 January 1992 (the day that the ParentSubsidiary Directive had to be implemented in national law) could never have been set up in order to gain an advantage, which arises from the Parent-Subsidiary Directive given that at that time, these advantages were not applicable.

In addition, the words 'arrangement' and 'series of arrangements' contain no link to the taxpayer ('company

\section{Notes}

97 The OECD PPT does not lay down the conditions for a 'tax advantage'. In the first Public discussion draft 'BEPS Action 6: Preventing the granting of treaty benefits in inappropriate circumstances, 14 Mar. 2014, OECD, point 21, it was still spoken of an arrangement 'to obtain a more favourable tax treatment', but in the 2014 Deliverable only 'benefit' was mentioned. Action 6: 2014 Deliverable, OECD p. 66, commentary 2 on the PPT rule. Also the final report mentioned only 'benefit' (commentary point 2).

98 CJ 20 May 2010, C-452/08 Zwijnenburg.

99 See: Room document \# 1, Working party on Tax Questions - Direct Taxation, PSD - Anti-abuse rule, 24 Jul. 2014, p. 2, published in: Highlights \& Insights on European Taxation, H\&I 2015/274 (comments by Dennis Weber).

100 Commission Recommendation of 6 Dec. 2012 on aggressive tax planning (2012/772/EU), OJEU 2012, L 338/41, para. 4.3. 
of a Member State') himself. Due to this, a taxpayer who does not play an active role in the arrangement (for example, a minority shareholder) can also be affected by the anti-abuse rule ${ }^{101}$.

Imagine that a company established in EU Member State $\mathrm{Z}$ has two shareholders established in two different non-EU States. One shareholder holds $75 \%$ of the shares and is established in non-EU State $\mathrm{X}$ and the other shareholder is established in non-EU Member State $\mathrm{Y}$ and holds $25 \%$ of the shares. When the EU company pays dividend to its $75 \%$ shareholder then $20 \%$ withholding tax is withheld by EU Member State Z, at payment of dividend to the $25 \%$ shareholder, on the basis of the applicable tax treaty between EU Member State $\mathrm{Z}$ and non-EU Member State Y, the withholding tax is reduced to $0 \%$. The two shareholders incorporate subholding $\mathrm{P}$ established in Member State N which subholding 100\% then holds the shares in the EU company in Member State $Z$. Due to this the payment of dividend from EU Member State $\mathrm{Z}$ to EU Member State $\mathrm{N}$ is exempt from withholding tax on the basis of the Parent-Subsidiary Directive and the payment of dividend of EU Member State $\mathrm{N}$ to its shareholders, due to the applicable tax treaty between EU Member State $\mathrm{N}$ and the non-EU countries is reduced to $0 \%$. The majority shareholders have advantage from the arrangement given that now, instead of $20 \%$, only $0 \%$ withholding tax is withheld on the dividend, and on the contrary, the $25 \%$ shareholders have no advantage. Also, for the direct holding of the shares, namely, no withholding tax was due on the dividend. It can be stated that the main purpose of the arrangement was to obtain a tax advantage. It is defendable that this purpose can only be allocated to the majority shareholders in non-EU Member State X, and not to the shareholders in non-EU Member State Y, certainly when this shareholder is not affiliated for the remainder. ${ }^{102}$ Nevertheless, it cannot be excluded that in such a case the anti-abuse rule is applicable because in the anti-abuse rule it is linked to the 'arrangement' and not to the taxpayer as such. It could thus be permitted that the source State, (in our example, EU Member State Z) in the case of a not genuine arrangement, has not taken into account the fact that one of the shareholders does not have a tax advantage. Whether this in fact should turn out to be disadvantageous for the minority shareholder who does not have a tax advantage, is dependent on the question what consequences should be attached to the finding of abuse. In my view, the arrangement which causes the abuse (in our case, the interposing of subholding $\mathrm{P}$ in EU Member
State N) would be ignored, in such a case, the situation before the interposition of the subholding has been reestablished and there is a dividend payment of an EU Member State directly to a parent company in a non-EU State. For the minority shareholder in our example, this would mean that there is no disadvantageous consequence because it can invoke the tax treaty concluded between EU Member State $Z$ and non-EU Member State Y, which provided for a tax rate of $0 \%$ (see further for the consequences of abuse paragraph 8.3).

It is not clear, however, what the consequences of abuse under the PSD are, so for the practice it is therefore recommended that in such a situation, the shareholder, which does not have a tax advantage does not cooperate with the interposing of such a subholding. If it does so, the consequence could be, namely, that on the basis of the common anti-abuse rule, the source State will levy withholding tax on dividends, which are ultimately due to such a (minority) shareholder, whereas he has had no benefit from the arrangement.

\subsubsection{Abuse Intention of Minority Shareholders}

Another question, which arises is how a subsidiary, which pays dividend to a minority shareholder can be aware of the fact that the minority shareholder is trying to abuse the directive. ${ }^{103}$ In first instance, the subsidiary will have to decide whether withholding tax on the paid dividend must be withheld and will be obliged to withhold dividend tax in the case of abuse. Unless in the case of an arrangement in which the subsidiary and the minority shareholder cooperate, the subsidiary could well be unaware of the motivation for abuse of its minority shareholder. The question thus is how to deal with this. Given that the directive itself does not provide any answer to this, the legislation of the Member States will have to provide the answer as to how to divide the burden of proof.

\subsection{Conflict with Object and Purpose of the Directive (Norm Test)}

Article 1, paragraph 2 formulates what I would call the norm test. There must be a tax advantage as main purpose or one of the main purposes of an arrangement, which 'defeats the object and purpose of this Directive'. There must thus be a matter of conflict with the purpose and object of the Directive.

\section{Notes}

101 See also: F. Debelva \& J. Luts, The General Anti-Abuse Rule of the Parent-Subsidiary Directive 226 (IBFD ET 2015). For a comparable finding on the principle purpose test in OECD BEPS action Plan 6: L. de Broe \& J. Luts, BEPS Action 6: Tax Treaty Abuse, Intertax 133 (2015) and M. Lang, BEPS Action 6: Introducing an Antiabuse Rule in Tax Treaties, TNI 659 (2014)

102 See also: O.C.R. Marres \& I.M. de Groot, De algemene antimisbruikbepaling in de moeder-dochterrichtlijn (deel 1), WFR 2015/7106, p. 890.

103 O.C.R. Marres \& I.M. de Groot, De algemene antimisbruikbepaling in de moeder-dochterrichtlijn (deel 2), WFR 2015/7107, para. 4.5. 
The CJ has ruled that the Parent-Subsidiary Directive has as objective "by the introduction of a common tax system, to eliminate any disadvantage to cooperation between companies of different Member States as compared with cooperation between companies of the same Member State and thereby to facilitate the grouping together of companies at Community level'. ${ }^{104}$ This is regarded by the $\mathrm{CJ}$ as the general objective of the directive there where the more specific object is to eliminate cases of double taxation of profits distributed by subsidiaries to their parent companies. ${ }^{105}$ We can thus assume that when an arrangement does not lead to the prevention of double taxation or does not lead to facilitating of the regrouping of companies within the EU this is in conflict with the object of the directive.

After the amendment of the PSD by Directive 2014/86/ $\mathrm{EU}$ in which an anti-hybrid instruments provision is included, the benefits of the PSD may also not lead to situations of double non-taxation and, therefore, generate unintended tax benefits for groups of parent companies and subsidiaries of different Member States when compared to groups of companies of the same Member State. 106

Although Article 1, paragraph 2 refers in general to the object and purpose of the PSD, I am of the view that in a concrete abuse situation also the object and purpose of the relevant provisions, which are avoided must be taken into consideration (for example, the conditions of tax residence, the condition of EU cross border dividend payment, etc.; see also paragraph 7.5.2.).

\subsection{Not Genuine (Artificiality)/Economic Reality-Test (Objectified Intention)}

\subsection{Artificial versus Business Reasons Which Reflect the Economic Reality}

Article 1, paragraph 2 also requires that the arrangement is 'not genuine'. It must concern an 'arrangement or a series of arrangements' which 'are not genuine having regard to all relevant facts and circumstances'. In Article 1 , paragraph 3 the following is added to the not genuine test: 'For the purposes of paragraph 2, an arrangement or a series of arrangements shall be regarded as not genuine to the extent that they are not put into place for valid commercial reasons which reflect economic reality'.

The Presidency also calls this the 'substance test'. ${ }^{107}$ In practice, I expect that in order to substantiate the common anti-abuse rule, the Member States will set substance requirements, which are based on Article 1, paragraph 3 (see also paragraph 7).

During the formation of the directive, it was observed that paragraph 3 'takes inspiration from Article 80 of the CCCTB proposal as included in the compromise text drafted by the Danish Presidency'. ${ }^{108}$ In the Danish Presidency CCCTB proposal, ${ }^{109}$ it was initially included in Article 80 (the General anti-abuse rule of the CCCTB) that 'artificial transactions or series of transactions carried out for the sole or main purpose of avoiding taxation shall be ignored for the purpose of calculating the tax base'. Next was included: 'the first paragraph shall not apply to genuine commercial activities carried out for valid commercial reasons'. The inspiration is clear, but one difference is that Article 1, paragraph 3 is formulated in the negative (double negative: 'not genuine'; and: 'not put into place'); there where the Danish proposal was formulated in the positive. In the last (Italian) compromise proposal of the CCCTB, for that matter a provision is included in Article 80, paragraph 2 which uses the same wording (thus with double negative) as Article 1, paragraph 3 of the PSD. ${ }^{110}$ It would seem that despite the other (positive or negative) formulation, the same is meant with the provision: in the case of an arrangement that is in place for valid commercial reasons, which reflect economic reality, the anti-abuse rule is not applicable.

We have seen here above that the main purpose or one of the main purposes of an arrangement must be the obtaining of a tax advantage (subjective test). It appears from the not genuine test that an arrangement is only abuse when this is not genuine and from paragraph 3 that there is no question of abuse when valid commercial reasons exist for the arrangement, which reflect an economic reality. The not genuine test and Article 1, paragraph 3 form part of the subjective test (paragraph 3 also mentions 'commercial reasons'), ${ }^{11}$ but Article 1 ,

\section{Notes}

104 See: 4 Oct. 2001, case C-294/99, Athinaiki Zythopoiia, para. 25

105 See: ECJ 22 Dec. 2008, case C-48/07, Les Vergers du Vieux Tauves, para. 37.

106 See consideration 2 of the preamble to Council Directive 2014/86/EU of 8 Jul. 2014 amending Directive 2011/96/EU on the common system of taxation applicable in the case of parent companies and subsidiaries of different Member States, OJ L 2014/219.

107 See: Room document \# 3, Working party on Tax Questions - Direct Taxation, PSD - Anti-abuse rule, 17 Sep. 2014, p. 2, published in: Highlights \& Insights on European Taxation, H\&I 2015/275 (comments by Dennis Weber).

108 See: Room document \# 1, Working party on Tax Questions - Direct Taxation, PSD - Anti-abuse rule, 24 Jul. 2014, p. 4, footnote 6, published in: Highlights \& Insights on European Taxation, H\&I 2015/274 (comments by Dennis Weber).

109 See: Council of the EU, 16 Apr. 2012, no. 2011/0058 (CNS), published in Highlight \& Insights on European Taxation, $2012 / 10.1$ (comments by Nouwen and Van de Streek).

110 See Brussels 19 Nov. 2014, 15756/14, LIMITE FISC 197, published in: Highlights \& Insights on European Taxation $2015 / 91$ (comments by Shuchien Chen).

111 See also F. Debelva \& J. Luts, The General Anti-Abuse Rule of the Parent-Subsidiary Directive 227 (IBFD ET 2015). 
paragraph 2 makes clear that for the existence of such reasons 'all relevant facts and circumstances' must be taken into consideration. The subjective intention, therefore, must be demonstrated from actual facts and circumstances (objectified intention). The preamble to the amending directive considers in this framework that the tax authorities must conduct an 'objective analysis' of all relevant facts and circumstances.

Article 1, paragraphs 2 and 3 set arrangements, which have an 'economic reality' against arrangements, which are 'not genuine'. It is unclear why Article 1 paragraphs 2 and 3 uses the term 'not genuine' and not 'artificial'. During the formation of the directive, it was observed that the proposed anti-abuse rule should 'build on the relevant case law of the Court of Justice' concerning the treaty freedoms. ${ }^{112}$ In the case law concerning the treaty freedoms, the Court speaks about artificiality; ${ }^{113}$ it would have thus been more obvious had the directive had also used the term artificiality instead of 'not genuine'. ${ }^{114}$ Also the Presidency, during the formation of the directive, used the terms 'an arrangement' that is 'artificially created to take undue advantage of the benefits provided for in the Directive'115. I, therefore, also assume that interpretation of the term 'not genuine' is the same as that of the term 'artificial'. 116

In this framework, I wish also to note that Article 1, paragraph 2 clearly requires that an arrangement must be 'not genuine' if there is to be a matter of abuse. In paragraph 3, the not genuine requirement is substantiated: 'An arrangement or a series of arrangements shall be regarded as not genuine to the extent that they are not put into place for valid commercial reasons which reflect economic reality'. This substantiation would seem to be logical and almost superfluous. It would seem, namely, clear that there is a matter of a genuine arrangement when this has been made for valid commercial reason, which reflects economic reality. This also follows from the formation history of paragraph 3, (from which it appears that inspiration has been drawn for the general anti-abuse provision from the CCCTB; see also further here above); in which it is clarified that paragraph 3 means that the antiabuse rule is not applicable in the case of an arrangement that is in place for valid commercial reasons.
For the sake of completeness, I wish to remark that Article 1 paragraph 3 can also be read differently. The term 'valid commercial reasons' is also set forth in the anti-abuse provision of the Merger Directive (Article 15). It appears from the Leur-Bloem judgment that the term valid commercial reasons from the Merger Directive is a concept involving more than the attainment of a purely fiscal advantage. ${ }^{117}$ Article 1, paragraph 3 could thus be read such that when the reason for an arrangement is a tax reason, the transaction is always also not genuine, because it has 'not [been] put into place for [a] commercial reason, which reflects economic reality'. What argues against this interpretation is that the not genuine test of Article 1, paragraph 2 then in fact adds nothing more. When tax reasons are always not genuine, then two requirements are made in Article 1, paragraph 2: (i) main purpose a tax advantage; and (ii) that defeats the object and scope of the Directive. This would seem to render the not genuine-test of Article 1, paragraph 2 (and the underscoring thereof in the preamble (consideration 6) a hollow phrase. In my opinion, therefore, Article 1, paragraph 3 must be read as a clarification. In that reading, this means that a tax advantage does not immediately mean that an arrangement is also not genuine. This reading better corresponds with the observations of the Presidency during the formation of the common anti-abuse rule which remarked, 'where an arrangement (...) is put into place that does not reflect an economic or business reality but is artificially created to take undue advantage of the benefits provided for in the directive', ${ }^{118}$ where with the term 'artificially', the Presidency would mean the 'not genuine test'. In addition, the Presidency noted that the proposed anti-abuse rule 'builds on the relevant case of the Court of Justice of the European Union on freedoms of establishment and free movement of capital by including: (1) a "substance test"; and (2) a "main purpose test"'119, whereby the not genuine test is thus also mentioned as a separate test (with the words substance test, the not genuine test is meant).

Besides, it is so that a reading where making use of a tax advantage as such is not labelled as not genuine, is in accordance with the case law of the CJ concerning the EU Treaty freedoms and thus, deserves preference. For

\section{Notes}

112 See: Room document \# 3, Working party on Tax Questions - Direct Taxation, PSD - Anti-abuse rule, 17 Sep. 2014, p. 2, published in: Highlights \& Insights on European Taxation, H\&I 2015/275 (comments by Dennis Weber).

113 See CJ 12 Sep. 2006, C-196/04, Cadbury Schweppes, para. 51

114 The Netherlands version of the directive does use the term 'artificial' (in Dutch: 'kunstmatig'), but this would seem to be an exception.

115 See: Room document \# 1, Working party on Tax Questions - Direct Taxation, PSD - Anti-abuse rule, 24 Jul. 2014, p. 2, published in: Highlights \& Insights on European Taxation, H\&I 2015/274 (comments by Dennis Weber).

116 See also: O.C.R. Marres \& I.M. de Groot, De algemene antimisbruikbepaling in de moeder-dochterrichtlijn (deel 1), WFR $2015 / 7106$, p. 892.

117 See as regards the Merger Directive: Leur-Bloem, case C-28/95, para. 47, confirmed in Foggia, case C-126/10, para. 34

118 See: Room document \# 1, Working party on Tax Questions - Direct Taxation, PSD - Anti-abuse rule, 24 Jul. 2014, p. 2, published in: Highlights \& Insights on European Taxation, H\&I 2015/274 (comments by Dennis Weber).

119 See: Room document \# 3, Working party on Tax Questions - Direct Taxation, PSD - Anti-abuse rule, 17 Sep. 2014, p. 2, published in: Highlights \& Insights on European Taxation, H\&I 2015/275 (comments by Dennis Weber). 
example, under the right of establishment, in Cadbury Schweppes, ${ }^{120}$ there was not immediately a matter of abuse when a taxpayer benefitted from a favourable tax regime in another Member State, and in Barbier, ${ }^{121}$ the CJ ruled that a taxpayer 'cannot be deprived of the right to rely on the provisions of the Treaty on the ground that he is profiting from tax advantages which are legally provided by the rules in force in a Member State other than his State of residence'122. In the SICES case $^{123}$ concerning tariff quotas, the $\mathrm{CJ}$ emphasizes when there is the intention to make use of a tax advantage this does not immediately imply abuse. What matters is whether certain transactions have been artificially designed in order to make use of a tax advantage.

It must be noted, however, that under the principle purpose test in the Merger Directive (which is comparable to the main purpose test from the PSD), the CJ did not apply an artificiality test. This is clear, for example, from the Foggia case, ${ }^{124}$ in which the $\mathrm{CJ}$ only examines whether tax considerations are predominant in comparison with the other reasons for a merger. Of importance, however, is that the principle objective test in the Merger Directive does not explicitly contain a not genuine test. This could thus be the reason for the $\mathrm{CJ}$, other than under the Treaty freedoms and in other cases, not to examine whether artificiality is present.

Finally, it is observed above that a "purely fiscal advantage' in the Leur-Bloem case is not considered a valid commercial reason. Fiscal advantages and fiscal reasons, thus also other fiscal benefits than those of the PSD (for example, being able to opt for a tax consolidation regime, more favourable tax system, etc.) cannot be considered a valid commercial reason. But also here, I repeat myself, when use is made of suchlike advantages, then there is no question of abuse when those reasons are genuine/not artificial.

In summary, it is clarified in Article 1, paragraph 3 that in the case of valid commercial reasons, which reflect economic reality, there is a genuine arrangement to which the anti-abuse rule is not applicable. Other fiscal reasons than the advantages, which flow from the
Parent-Subsidiary Directive are not valid commercial reasons (for example the entering into a tax consolidation regime, being able to opt for a more favourable tax system, etc). In addition, it appears from paragraph 3 (read in conjunction with paragraph 2) that the arrangement must be 'not genuine' (artificial) if this is to qualify as abuse. The fact that an arrangement has been set up for fiscal reasons does not have to mean that the arrangement is not genuine or artificial.

\section{When IS THERE ABUSE}

\section{I What Is Abuse under the Common Anti-Abuse Rule}

Above, I have discussed the three tests of the anti-abuse rule in a more abstract form. In this paragraph, I endeavour to discuss more specifically what abuse situations the anti-abuse rule provides for. This, however, is not so easy. No explanation (no explanatory memorandum) is given to the directive amendment of abuse situations to which the amendment applies. We only have an example in the preamble (see paragraph 7.3. hereafter), and besides that, as appears from various preparatory documents from the amending directive, ${ }^{125}$ directive shopping in order to avoid withholding tax on dividend paid to companies established in third countries is an important reason for the anti-abuse rule. Although the avoidance of withholding tax in third country situations is an important reason for the introduction of the common anti-abuse rule (the Italian Presidency called it the 'the most common case'), ${ }^{126}$ it cannot be derived from the text of the anti-abuse rule and the preamble that the scope is limited to suchlike abuse. ${ }^{127}$ the scope is thus broader, on the basis of the text the common anti-abuse rule is applicable in each situation in which the benefits of the directive are abused. The benefit of the directive is the advantage on the basis of Article 4 (prevention of economic double taxation) and the advantage on the basis of Article 5 (exemption from dividend tax) (see here above also paragraph 5.4).

\section{Notes}

120 ECJ 12 Sep., case C-196/04, Cadbury Schweppes, paras 34-38.

121 ECJ 11 Dec. 2003, case C-364/01, Barbier, para. 71.

122 See also: K. Lenaerts, The Concept of 'Abuse of Law' in the Case Law of the European Court of Justice on Direct Taxation, Maastricht J. Eur. \& Comp. L. 329 (2015).

123 CJ 13 Mar. 2014, case C-155/13, SICES, para. 38.

124 CJ 10 Nov. 2011, C-126/10, Foggia.

125 Question and Answers on the Parent-Subsidiary Directive, Brussels, 25 Nov. 2013, MEMO/13/1040 and see: Room document \# 1, Working party on Tax Questions Direct Taxation, PSD - Anti-abuse rule, 24 Jul. 2014, p. 3, published in: Highlights \& Insights on European Taxation, H\&I 2015/274 (comments by Dennis Weber).

126 Room document \# 1, Working party on Tax Questions - Direct Taxation, PSD - Anti-abuse rule, 24 Jul. 2014, p. 3, published in: Highlights \& Insights on European Taxation, H\&I 2015/274 (comments by Dennis Weber).

127 Different: O.C.R. Marres \& I.M. de Groot, De algemene antimisbruikbepaling in de moeder-dochterrichtlijn (deel 2), WFR 2015/7107, p. 915, die de reikwijdte beperken tot directive shopping. 
With regard to Article 4, for example, we can consider situations such as were in dispute in the French Sagal case $^{128}$ or the $\mathrm{S} A$ Natixis banques populaires case ${ }^{129}$ in which the French participation exemption (and the PSD) was not applied under the French abuse of law rule because the foreign subsidiary had too little economic substance. In these cases, the intermediate holding companies were interposed with as object to convert interest payments to dividend in order thus to be able to make use of the French participation exemption and the PSD. Probably, under the anti-abuse rule, it will now be mandatory to combat these types of situations in every Member State. ${ }^{130}$

With regard to the abuse of the exemption from dividend tax of Article 5, first to be considered is the situation of directive shopping in relation to third countries (see below extensively in paragraph 7.4.). In addition, this exemption can also be abused in situations within the EU. For example, in a situation in which just before a dividend payment, a shareholding is quickly extended in order to satisfy the $10 \%$ holding requirement of the PSD and thus an exemption from withholding tax is applicable, to subsequently, after the dividend payment, bring the shareholding again below $10 \% .131$

In the November 2013 proposal for a general anti-abuse provision and in the Commission Recommendation on aggressive tax planning ${ }^{132}$ (which are almost the same), a number of situations are mentioned, which indicate artificiality. The Member States, however, have explicitly indicated that they will not include this list in the common anti-abuse rule because it is 'too generic and not sufficiently tailored to cover specific PSD situations'. ${ }^{133}$ Because it is therefore unclear what the use of this list is, I shall not discuss the examples from the list further here. $^{134}$

For the sake of completeness, I also note the Resolution of the Council of 8 June 2010 on coordination of the Controlled Foreign Corporation (CFC) and thin capitalisation rules within the European Union. ${ }^{135}$ This Resolution was not discussed at the formation of the common anti-abuse rule, but specifies a number of circumstances where a "political "commitment" exists that there is a matter of abuse'. ${ }^{136}$

\subsection{What Circumstances Are of Importance for the Not Genuine/Artificialityl Economic Reality Test (Substance)}

Article 1, paragraph 2 requires for the existence of abuse, an 'arrangement or a series of arrangements' which 'are not genuine having regard to all relevant facts and circumstances'. In Article 1, paragraph 3 the following is added to the not genuine test: 'For the purposes of paragraph 2, an arrangement or a series of arrangements shall be regarded as not genuine to the extent that they are not put into place for valid commercial reasons which reflect economic reality'.

\section{Notes}

128 Conseil d'Etat 18 May 2005, N²67087, Sagal.

129 Conseil d'Etat 11 May 2015, N 365564, SA Natixis banques populaires.

130 See on the French abuse doctrine and the relation to EU Law: L. Leclercq, Interacting Principles: The French Abuse of Law Concept and the EU Notion of Abusive Practices, ET 235 (2007); E. Robert \& D. Tof, The Substance Requirement and the Future of Domestic Anti-Abuse Rules within the Internal Market, ET 436 (2011) and B. Gouthiere, French AntiAbuse International Tax Legislation: Recent Developments 514 (ET 2006).

131 A Member State can prevent this type of abuse by incorporating the (non-mandatory) minimum holding period of two years (Art. 3(2)) in its national legislation. The question is when a Member State has not incorporated the minimum holding period in its legislation whether this Member State is obliged after all under Art. 1, para. 2 to combat abuse in this type of situation. According to Kok, in such a situation, under the OECD PPT rule there can no longer be a question of abuse: Q.W.J.C.H Kok, Enkele aspecten van de 'principle purpose test', WFR 2015/7083, p. 184

132 Commission Recommendation of 6 Dec. 2012 on aggressive tax planning (2012/772/EU), OJEU 2012, L 338/41.

133 See: Room document \# 3, Working party on Tax Questions - Direct Taxation, PSD - Anti-abuse rule, 17 Sep. 2014, p. 2, published in: Highlights \& Insights on European Taxation, H\&I 2015/274 (comments by Dennis Weber) and Room document \# 1, Working party on Tax Questions - Direct Taxation, PSD - Anti-abuse rule, 24 Jul. 2014 , p. 3, published in: Highlights \& Insights on European Taxation, H\&I 2015/274 (comments by Dennis Weber).

134 For the sake of completeness; It concerns the following list:

(a) the legal characterisation of the individual steps which an arrangement consists of is inconsistent with the legal substance of the arrangement as a whole;

(b) the arrangement is carried out in a manner which would not ordinarily be used in a reasonable business conduct;

(c) the arrangement includes elements which have the effect of offsetting or cancelling each other;

(d) the transactions concluded are circular in nature;

(e) the arrangement results in a significant tax benefit which is not reflected in the business risks undertaken by the taxpayer or its cash flows. In the Commission Recommendation on aggressive tax planning was added:

the expected pre-tax profit is insignificant in comparison to the amount of the expected tax benefit.

135 See in this framework also: Commission Communication of 10 Dec. 2007 to the Council, the European Parliament and the European Economic and Social Committee entitled 'The application of anti-abuse measures in the area of direct taxation - within the EU and in relation to third countries' [COM(2007) 785 final.

136 Resolution of the Council of 8 Jun. 2010 on coordination of the Controlled Foreign Corporation (CFC) and thin capitalisation rules within the European Union, OJ EU 2010, C156/1. 
This is called the 'substance test' by the Italian Presidency and also in literature. ${ }^{137}$

What circumstances are relevant to the question whether there is abuse is dependent on the legislation, which is avoided and the specific transaction or arrangement. ${ }^{138}$ The question under what circumstances is there a matter of an arrangement which is 'not genuine'; 'artificial' or has an economic reality is thus different every time. ${ }^{139}$

Circumstances that could be relevant are: if there is directive shopping within or outside of the EU, or that there is a situation in which, for example, (taxed) interest is converted to untaxed dividend. In all those situations, there is a matter of other forms of abuse and other applicability conditions of the PSD are misused. In all these situations, thus, other facts and circumstances are relevant.

In literature, ${ }^{140}$ but also by the Italian Presidency, ${ }^{141}$ for the substantiation of the not genuine test a direct link is made to the substance test that the CJ applied in Cadbury Schweppes in a situation in which the UK wanted to apply CFC legislation in the situation where use was made of the right of establishment but in which, according to the UK, there was a matter of the artificial shifting of profits of the one Member State to another Member State.

I should like to make a general remark on this that it is very doubtful whether the substance-requirements, which have been formulated in particular under the right of establishment can be applied one-for-one under the Parent-Subsidiary Directive. Contrary to the Italian Presidency, I am of the opinion that this is not the case. Under the right of establishment, for example, the performing of economic activities in another Member
State is of importance (otherwise the right of establishment is not exercised) and the objective of the right of establishment is economic and social interpenetration within the Community. ${ }^{142}$ The applicability conditions of the Parent-Subsidiary Directive do not require economic activities in another Member State and the object and purpose of that directive is different to that of the Treaty Freedoms (see here above paragraph 6.3). Also under the right of establishment itself are the same substance conditions not always applied such as was under discussion in Cadbury Schweppes. For example, in the Thin Cap GLO, for the question whether there was abuse, the Court found relevant whether the interested party had 'any commercial justification' for a loan and/or the amount of the interest paid. These are different 'substance' requirements than those from Cadbury Schweppes. ${ }^{143}$

In my view, we can be inspired by the abuse case law under the treaty freedoms (thus also by Cadbury Schweppes), but in addition, we must tread with caution in the analogous application of the case law on other areas of EU law given that this is based on legislation, which has other conditions and other objectives (see further also, paragraph 7.4.1).

\subsection{Case Law of the CJ Regarding Economic Reality}

Article 1, paragraph 3 of the directive, the term 'economic reality' is used. I anticipate that in the future, this term will play a large role in the substantiation of what is abuse under the PSD. In the case law of het CJ, the term

\section{Notes}

137 With regard to CFC-legislation, the Resolution determines: 'A. For the application of CFC rules, a non-exhaustive list of indicators suggesting that profits may have been artificially diverted to a CFC includes in particular the following:

(a) there are insufficiently valid economic or commercial reasons for the profit attribution, which therefore does not reflect economic reality;

(b) incorporation does not essentially correspond with an actual establishment intended to carry on genuine economic activities;

(c) there is no proportionate correlation between the activities apparently carried on by the CFC and the extent to which it physically exists in terms of premises, staff and equipment;

(d) the non-resident company is overcapitalised, it has significantly more capital than it needs to carry on its activity; (e) the taxpayer has entered into arrangements which are devoid of economic reality, serve little or no business purpose or which might be contrary to general business interests, if not entered into for the purpose of avoiding tax.

138 See: Room document \# 3, Working party on Tax Questions - Direct Taxation, PSD - Anti-abuse rule, 17 Sep. 2014, p. 2, published in: Highlights \& Insights on European Taxation, H\&I 2015/275 (comments by Dennis Weber), R.J.S. Tavares \& B.N. Bogenschneider, The New De Minimis Anti-abuse Rule in the Parent-Subsidiary Directive: Validating EU Tax Competition and Corporate Tax Avoidance?, 8\&9 Intertax 484 (2015).

139 See also K. Lenaerts, The Concept of 'Abuse of Law' in the Case Law of the European Court of Justice on Direct Taxation, Maastricht J. Eur. \& Comp. L. 329 (2015); E. Robert \& D. Tof, The Substance Requirement and the Future of Domestic Anti-Abuse Rules within the Internal Market 436 (ET 2011); E. Picq, Abuse of EU Holding Companies: Fundamental Freedoms, EC Parent-Subsidiary Directive and the French Constitution, - Part 1474 (ET 2009); H. van den Hurk, De introductie van een algemene anti-abuse provision zet de Europese Unie jaren terug in de tijd, WFR 2014/7051, p. 732; See also: Communication from the Commission, The application of anti-abuse measures in the area of direct taxation - within the EU and in relation to third countries, Brussels 10.12.2007, COM (2007) 785 final, p. 5.

140 See in that framework also Sorensen, who comes to the conclusion that the misuse of letterbox companies differs very much from sector to sector, so a sectoral approach is better to combat abuse of letterbox companies; see: K.E. Sorensen, The Fight against Letterbox Companies in the Internal Market, CMLRev. 85 (2015).

141 Differently: B.J. Wolf \& A.Q.C. van Vuuren, The Case Fred Olsen and the Adjusted Parent-Subsidiary Directive: The Substance Requirements within the European Abuse Concept, WFR 7100, p. 743, which assumes that under Art. 1, para. 2 of the Parent-Subsidiary Directive mainly consistence will be sought with the substance test in Cadbury Schweppes and Olsen.

142 Room document \# 1, Working party on Tax Questions - Direct Taxation, PSD - Anti-abuse rule, 24 Jul. 2014, p. 3, published in: Highlights \& Insights on European Taxation, H\&I 2015/274 (comments by Dennis Weber).

143 See: case 2/74, Reyners [1974] ECR 631, para. 21. 
economic reality is brought up more often. ${ }^{144}$ As I remarked here above, we must realize that the case law is focussed on the specific type of (assumed) abuse, which is under discussion in the relevant case. With a degree of caution, general conclusions can thus be reached from the relevant judgments. Also of importance is that in the VAT case Newey, ${ }^{145}$ for the determination of the economic and commercial reality, the CJ assumed the contractual provisions as starting point, because they usually reflect the economic and commercial reality and for the sake of legal certainty. In Newey, however, the CJ instructs the national court to examine whether on the basis of facts and circumstances the contractual provisions do in fact truly reflect the economic reality.

With regard to the term economic reality, an anthology from the case law shows the following:

- In Cadbury Schweppes, the objective elements on the basis of which interested parties can prove that an economic reality physically exists were in terms of premises, staff and equipment. ${ }^{146}$

- In the Thin Cap GLO case, this was any commercial justification that there may have been for that arrangement. ${ }^{147}$

- In Weald Leasing, a lease price which was 'unusually low'. ${ }^{148}$

- In RBS Deutschland, the CJ found it important whether there were arm's-length transactions or whether there were transactions between parties who were legally unconnected and that they were carried out in the context of normal commercial operations. ${ }^{149}$

- In Part Services, it was important if the transaction could only be considered 'economically unprofitable'. ${ }^{150}$

- In SICES, transactions may not a priori be regarded as being devoid of economic and commercial justification; abuse could be the case when there is no question of any commercial risk; if the profit margin is insignificant or prices lower than the market price. ${ }^{151}$

- In Emsland-Starke, if there were legal, personal and commercial links and if there was collusion. ${ }^{152}$

\subsection{U-Turns Are Artificial}

It can be derived from Emsland-Starke, Leclerc, Lasteyrie, Glaxo Wellcome, Kofoed, that the CJ is sensitive to what I call U-turns, or only making use of the free movement in order to enjoy a fiscal advantage. These u-turns characterize themselves usually because they have been set up for a limited period. In short, it concerns the 'the adhoc formation of legal structures' (compare: Ampliscientifica ${ }^{153}$ ). In the Lasteyrie case, ${ }^{154}$ The CJ ruled that an emigration levy was a too general abuse provision for the purpose of combating tax avoidance. The object of the emigration levy, namely preventing that a taxpayer who wishes to sell securities first temporarily relocates his place of residence, with as sole purpose to escape the French tax on capital appreciations, could according to the CJ, also be achieved with measures which hinder or restrict the freedom of establishment less, and bear specific relation to the risk of such a temporary relocation: 'As the Advocate General has pointed out in paragraph 64 of his Opinion, the French authorities could, for example, provide for the taxation of taxpayers returning to France after realizing their increases in value during a relatively brief stay in another Member State, which would avoid affecting the position of taxpayers having no aim other than the bona fide exercise of their freedom of establishment in another Member State' (paragraph 54). Here, we see an example of a u-turn.

There are more examples of a number of so-called $u$ turn situations to be found in the case law. For example,

\section{Notes}

144 CJ 13 Mar. 2007, C-524/04, Thin Cap GLO case concerned the question whether a group loan and the interest thereon were at arms length. Where there was a transaction which was not arm's-length, there could still be a matter of an economic reality when the interested party had 'any commercial justification' for the arrangement (thus for the loan and/or the interest). This is separate from the economic substance such was in question in, for example, Cadbury Schweppes, the economic reality could be demonstrated by submitting proof of the physical existence of the Irish financing company in terms of premises, staff and equipment. Having a certain degree of substance can, therefore, be relevant in one situation and not relevant in the other, given that it says nothing about the tax avoidance, which was under dispute in the concrete case. The substance can also be different. What is relevant as substance in the one situation is not relevant in the other. See as comparison: M. Poulsen, Treaty/Directive Shopping and Abuse of EU Law, 4 Intertax 245 (2013).

145 See extensively: Dennis Weber, Abuse of Law in European Tax Law: An Overview and Some Recent Trends in the Direct and Indirect Tax Case Law of the ECJ, European Taxation 2013/6 (part 1), 2013/7 (part 2)

146 CJ 20 Jun. 2013, case C-653/11, Paul Newey.

147 CJ 12 Sep., case C-196/04, Cadbury Schweppes, para. 67

148 CJ 13 Mar. 2007, case C-524/04, Thin Cap GLO, para. 82.

14922 Dec. 2010, case C-103/09, Weald Leasing, HEI 2011/3.10 (comments by De la Feria).

15022 Dec. 2010, case 277/09, RBS Deutschland, paras 50 and 51 .

15121 Feb. 2008, case C-425/06, Part services, para. 57.

15213 Mar. 2014, case C-155/13, SICES, paras 38 and 39

153 CJ 14 Dec. 2000, case C-110/99, Emsland-Stärke, para. 59.

15422 May 2008, case C-162/07, Ampliscientifica, para. 31 
Emsland-Stärke, ${ }^{155}$ export and almost simultaneously reimport of a good for the purpose of obtaining an advantage. Here, this would seem to be a situation of abuse. The Leclerc judgment ${ }^{156}$ is another example. In this case, books were first exported and later imported again in the same Member State, thus there was equally a u-turn. The CJ considered in this case that abuse arose 'where it is established that the books in question were exported for the sole purpose of re-importation in order to circumvent legislation of the type at issue'. In the November 2013 proposal for a general anti-abuse provision and in the Commission Recommendation on aggressive tax planning, ${ }^{157}$ an example that indicates artificiality is the fact that 'the transactions concluded are circular in nature'. This also seems to indicate u-turns.

\subsubsection{Absence of Permanence}

As I observe here above, u-turns are often characterized by the fact that they are set up for a limited period. Permanence therefore, is lacking. We see this element back in the case law. In the Glaxo Wellcome case, AG Bot observed that a fiscal advantage that arises due to, within a group, a foreign Group company selling shares to a German company followed by fast selling on to a (same) foreign group company, justifies a suspicion of tax avoidance.

It appears from Leur-Bloem ${ }^{158}$ that a shares merger with the aim of creating a specific structure for a limited period of time and not on a permanent basis may constitute evidence of tax evasion or tax avoidance (see paragraph 42).

I wish to point out that in my view, the above does not mean that when a structure has been created for the longterm, there will never be abuse. Even a long-term structure can have no economic reality. ${ }^{159}$

\subsubsection{Interposing of Holding Companies in the Case Law of the CJ (Leur-Bloem and Kofoed)}

The interposing of holding companies for fiscal reasons has been brought up in the case law of the CJ. It appears from this case law that the fact that a holding company is included in a certain structure, which is only a shareholder and for the remainder, has no substance, does not as such say anything about the question whether there is abuse. the creating of a holding company as such, therefore, is still not abuse. ${ }^{160}$

\subsubsection{Leur-Bloem Case}

We can see that, for example, in the Leur-Bloem judgment. ${ }^{161}$ In that case, a sole shareholder and director of two companies established in the Netherlands wanted to set of the loss of the one company with the profit of the other company. In the Netherlands, such horizontal loss relief is possible under the fiscal unity (fiscale eenheid) regime, but for this, a company (at the time) had to own $100 \%$ of the shares in both companies. In order to achieve this, a holding was incorporated which, by means of an exchange of shares, acquired the shares in the two companies. After this exchange of shares, Leur-Bloem held indirectly a $100 \%$ interest in the two companies (via a $100 \%$ interest in the holding) and the two companies with the holding company were able to form a fiscal unity. Subsequently, within the fiscal unity, profits and losses could be set off horizontally. The Netherlands legislation laid down as condition for an untaxed exchange of shares that there had to be 'merging the business of two companies permanently in a single unit from a financial and economic point of view'. This condition was not fulfilled, because in the subject case there was a matter of a holding (which did not have a 'business' itself) and because the 'single unit' already existed because both companies had the same director and sole shareholder. In fact here, by means of a shares merger, a holding company is interposed in order to obtain a tax advantage (horizontal loss set-off). In addition, the Nederlands in fact applied a substance requirement (only untaxed shares merger if the company has a 'business'). In the final judgment in Leur-Bloem it is, on the one hand, clear that the $\mathrm{CJ}$ is of the opinion that horizontal loss set-off is not a commercial reason (but merely striving for a pure tax advantage) and, on the other, that a shares merger whereby a holding company is created cannot, in advance, be considered tax avoidance. The CJ considered in Leur-Bloem in paragraph 42: 'A merger or a restructuring carried out in the form of an exchange of shares involving a newly-created holding company which does not therefore have any business may be regarded as

\section{Notes}

15511 Mar. 2004, case C-9/02, Hughes de Lasteyrie du Saillant.

156 CJ 14 Dec. 2000, case C-110/99, Emsland-Stärke.

157 CJ 10 Jan. 1985, case 229/83 (Leclerc), Jur. p. 1, para. 27.

158 Commission Recommendation of 6 Dec. 2012 on aggressive tax planning (2012/772/EU), OJEU 2012, L 338/41.

159 ECJ 17 Jul. 1997, case C-28/95 (Leur-Bloem), BNB 1998/32.

160 O.C.R. Marres \& I.M. de Groot, De algemene antimisbruikbepaling in de moeder-dochterrichtlijn (deel 1), WFR 2015/7106, p. 893.

161 See also: F. Debelva \& J. Luts, The General Anti-Abuse Rule of the Parent-Subsidiary Directive 223 (IBFD ET 2015) and M. Poulsen, Treaty/Directive Shopping and Abuse of EU Law, 4 Intertax 246 (2013). 
having been carried out for valid commercial reasons. Similarly, such reasons may render necessary the legal restructuring of companies which already form an entity from the economic and financial point of view. Even if this may constitute evidence of tax evasion or tax avoidance, it is nevertheless possible that a merger by exchange of shares with the aim of creating a specific structure for a limited period of time and not on a permanent basis may have valid commercial reasons'. The Netherlands substance requirement that the companies must operate a business was too general and thus in conflict with the anti-abuse provision from the Merger Directive.

\subsubsection{Kofoed Case}

Another example of a judgment in which the matter was the interposing of a holding company is the Kofoed-case. ${ }^{162}$ This case, concerned a Danish company with two Danish shareholders. When the Danish company paid dividend to its shareholders, 43\% Danish dividend tax had to be paid. ${ }^{163}$ In the case, an Irish company was incorporated (described by the AG as a 'dormant' company ('shell company')). ${ }^{164}$ The shares in the Danish company were transferred to the Irish company and subsequently, three days later, a dividend was paid by the Danish company to the Irish Holding and then to the Danish shareholders. No tax was due on that in Ireland and no dividend tax in Denmark (on the basis of the Parent-Subsidiary Directive). The exchange of shares and the decision to proceed to profit distribution both took place shortly before a new Danish-Irish Treaty on the prevention of double taxation entered into effect, whereby for the taxation of dividends, rules would be implemented, which were less favourable than those which applied for Danish taxpayers based on the then applicable treaty. The Danish Tax Authorities in this case were to refuse the exemption for the shares exchange such as prescribed by the Merger Directive, amongst others, arguing that this was tax avoidance. The CJ left the assessment whether there was a matter of tax avoidance to the national court, but the AG had observed (points 58 and 59): 'According to Article 11(1)(a) of Directive 90/434, Member States are permitted, however, to refuse to apply or withdraw the benefit of all or any part of the tax advantages provided by that directive in connection with an exchange of shares if such a transaction has tax evasion or tax avoidance as its principal objective or as one of its principal objectives. As a general example of such an objective, the second sentence of Article 11(1)(a) of Directive 90/434 mentions the situation in which valid commercial reasons for the transaction concerned are absent. In a case such as the present one, in which, according to the facts as found by the referring court, no specific commercial reason existed for the transaction, rather its objective was to save tax, a refusal to apply the tax exemption provided by Article 8(1) of Directive 90/434 may certainly be considered. An exchange of shares by which it is sought purely to attain tax advantages does not serve a valid commercial purpose within the meaning of the directive. Leaving that matter to one side, the close connection in terms of time between the distribution of profits and the exchange effected may point also towards possible abuse of the options presented by Directive 90/434. The same can be said also of the fact that the parties acted with knowledge of the imminent amendment to the Danish-Irish double taxation convention'. In this case, we see an example of a structure, which is carried out in a very short period of time simply to obtain a tax advantage. Such ad hoc structures, set up without permanence, lack economic reality and therefore, are artificial. The Kofoed case comes close to the discussion on directive shopping in connection with third countries under the Parent-Subsidiary Directive. In the Kofoed case, the Danish tax law endeavours to combat the structure by refusing the exemption in the Merger Directive, but another option could have been to refuse the exemption from levy of dividend tax at the dividend payment of the Danish company to its Irish parent.

It is clear from Leur-Bloem and Kofoed that the interposing of a (shell) holding company as such does not have to constitute abuse, even more so, the starting point is that here, there is no question of this unless there is something that indicates abuse. Substance requirements such as the operating of a business are too general, in the light of the fact that a holding is then always abuse (LeurBloem). Indications of abuse can be that a certain structure has not been set up to be permanent (but for a limited period) (Leur-Bloem and AG in Kofoed). Such as I have also explained in paragraph 7.3.2. we see suchlike elements more often in the case law of the CJ.

\subsection{Abuse Example from the Preamble}

In consideration 8 of the preamble to the amending directive, an example is given of an abuse situation: 'The "to the extent approach" can be effective in cases where the entities concerned, as such, are genuine but where, for example, shares from which the profit distribution arises are not genuinely attributed to a taxpayer that is

\section{Notes}

162 Case C-28/95, Leur-Bloem.

163 Case C-321/05, Kofoed.

164 See: T. Ronfeldt, Tax Havens and Tax Shelters, 4 Intertax 341 (2015). 
established in a Member State, that is, if the arrangement based on its legal form transfers the ownership of the shares but its features do not reflect economic reality'.

What is clear to me is that a distinction is made between the entities as such, which can be genuine (and thus have economic reality) and the allocating of the shares to the taxpayer, which is not genuine (and thus, which allocation has no economic reality). In other words: the fact that the entities are genuine does not have to say that also the holding of shares by those entities and in those entities is genuine. This means, for instance, that when the entities involved are genuine because of the fact that they have sufficient economic substance (for instance, economic activities), the ownership of the shares as such can still be abusive. This means that when the entities have economic substance (in the sense of economic activities) this does not always mean that the common anti-abuse rule is not applicable.

It is not clear when the 'transfer' of the 'ownership of the shares' does not reflect economic reality. Under the OECD PPT rule in Action 6, in this framework examples of abusive arrangements are given in which the usufruct of shares (or the right to payment of dividend) ${ }^{165}$ in order to claim the benefit of a tax treaty (lower withholding tax) are used. The example under the OECD PTT regarding the holding of shares in usufruct (or a right to payment of dividend), cannot be applicable under the PSD given that the holding of shares in usufruct does not fall under the term 'holding in the capital of a company', such as is shown from the Les Vergers du Vieux Tauves judgment ${ }^{166}$ and thus the Parent-Subsidiary Directive will not be applicable at all. Marres and De Groot ${ }^{167}$ note that the example from the preamble will be meant for the situations in which a multinational does have an active company in an EU Member State, but those activities are irrelevant for the holding of the shares, and those shares were transferred to this company mainly with the view to obtaining the advantages of the PSD. They thus read in the example of the preamble that there must be a certain link between the activities of the company and the holding of the shares. I cannot read from the preamble that such a link is required, although I do agree with them that when there is a certain link between the holding of the shares and the activities of the company the holding of the shares seems to have an economic reality (see on this also paragraph 7.5 . below)

\subsection{Directive Shopping to Circumvent Withholding Tax on Dividend to Third States}

\subsection{The Italian Presidency Example}

The most common example of abuse under the new antiabuse rule is directive shopping to avoid withholding tax on dividend paid to non-EU countries. This example of abuse had already been given in the Q\&A-memo to the November 2013 proposal ${ }^{168}$ and the Italian Presidency called it 'the most common case'. The Italian Presidency gave the following example to the Working Party on Tax Questions of 24 July 2014:169

For example, the most common case is that of a company (A) of a third country, which has a holding in the capital of a company (B) situated in a Member State, interposes in the holding chain another EU company (C), for the sole purpose of benefitting from the exemption/credit granted under the Directive. Such arrangements, in general, also exploit favourable provisions laid down in the double tax convention between the third State and the State where the interposed company is situated.

The general anti-abuse rule is aimed at denying the benefits of the Directive where the interposition of company $\mathrm{C}$ does not reflect economic reality, but is designed to benefit from an exemption scheme to which company A would not otherwise be entitled.

Thus, in this example, a Member State could use the anti-abuse provision if company $\mathrm{C}$ has no economic substance nor participates actively in the commercial reality in the Member State of establishment, playing the role of a mere intermediary in the flow of payment of the dividends.

The Presidency believes that these cases, where they are not governed by domestic law (because the Member State concerned do not have an anti-abuse rule or because the domestic anti-abuse rule does not fit in the PSD or is not sufficiently strict), should be regulated by an EU anti-abuse rule, which Member States would have to transpose into national legislation, to prevent circumvention of the Directive.

With regard to the evaluation of the economic reality of the interposed company, reference can only be made to

\section{Notes}

165 Opinion AG Kokott, C-321/05, Kofoed, point 25.

166 Preventing the granting of treaty benefits in inappropriate circumstances, Action 6: final report, OECD/G20 Base Erosion and Profit Shifting project, 5 Oct. 2015, commentary on the PPT rule: point 14, examples A and B.

167 CJ 22 Dec. 2008, case C-48/07, Les Vergers du Vieux Tauves.

168 O.C.R. Marres \& I.M. de Groot, De algemene antimisbruikbepaling in de moeder-dochterrichtlijn (deel 1), WFR 2015/7106, p. 893.

169 Question and Answers on the parent subsidiary Directive, Brussels, 25 Nov. 2013, MEMO/13/1040. 
the criteria identified by the Court of Justice of the European Union on freedom of establishment and free movement of capital. Consequently, what should be assessed is the significant physical presence of the EU company which participates, on a stable and continuous basis, in the economic life of a Member State, by carrying out a real economic activity. ${ }^{170}$

It is understood that such evaluation could be graduated according to the activity performed by the company. This is especially true for holdings which, by their nature, do not require a major organization in terms of resources and staff.

In addition, the introduction of this rule would also solve those cases where actual establishments do exist but which, however, are misused to obtain the benefits of the Directive, through the implementation of operations and transactions for which there is no real economic rationale.

Noteworthy in the example is that the Italian Presidency is of the opinion that the interposed company has no economic reality when it has no economic substance nor participates actively in the commercial reality in the Member State of establishment, playing the role of a mere intermediary in the flow of payment of the dividends'. In addition, for the question whether the interposed company has an economic reality, it refers to the case law of the CJ concerning the freedom of establishment and free movement of capital, from which it is concluded 'Consequently, what should be assessed is the significant physical presence of the EU company which participates, on a stable and continuous basis, in the economic life of a Member State, by carrying out a real economic activity'. This is watered down for holdings, 'which by nature, do not require a major organization in terms of resources and staff', according to the Presidency.

The Italian Presidency thus clearly reads an economic substance requirement in the anti-abuse rule, in either (i) the State where the interposed company is established (company C) or (ii) that the interposed company actively participates in the commercial reality in the Member State of establishment of the company (company B) in which it holds the shares. The economic reality requirement would also seem to entail an 'economic activity requirement', given that reference is made to the case law concerning the right of establishment (Gebhard/Cadbury Schweppes) in which a 'real economic activity' is required. Of importance, however, is that the Italian Presidency remarks that when an intermediate holding company (company $\mathrm{C}$ in the example) 'has no economic substance' there is no question of an economic reality. It is tempting to attach the conclusion to this that when there is economic substance, there will always be an economic reality. From the preamble of the directive, however, it seems that also when the entity itself has an economic reality, the holding of the shares as such still does not have to have an economic reality (see further paragraph 7.3 here above). The interpretation of the expressions of the Presidency thus, in my view, must be limited.

We also see that for the question what is an economic reality within the meaning of the PSD, the Italian Presidency refers ${ }^{171}$ to the explanation of this term under the treaty freedoms and in particular, to the Cadbury Schweppes judgment. ${ }^{172}$ Also in literature, we see that for the term economic reality, a link is sought with the criteria from Cadbury Schweppes. ${ }^{173}$ In this judgment, the CJ, for the evidence that there was an economic reality, deemed sufficient that the taxpayer could submit proof of the physical existence of an Irish financing company in terms of premises, staff and equipment. In addition, in Cadbury Schweppes, the CJ observed (paragraph 68): 'If checking those factors leads to the finding that the CFC is a fictitious establishment not carrying out any genuine economic activity in the territory of the host Member State, the creation of that CFC must be regarded as having the characteristics of a wholly artificial arrangement. That could be so in particular in the case of a "letterbox" or "front" subsidiary (see Case C-341/04 Eurofood IFSC [2006] ECR I-0000, paragraphs 34 and 35)'. Of importance, in my view, is that in Cadbury Schweppes, CFC legislation was under discussion, which provided for the prevention of profit shifting (in this case, from the United Kingdom to Ireland). The question thus was whether taxation on profits from activities performed in the United Kingdom was avoided. The physical existence of the Irish financing company (premises, staff and equipment) was sufficient to assume that there were Irish and not English profits, and that there was thus no question of an artificial shift. ${ }^{174}$

Such as I have observed in paragraph 7.2., the direct application of the substance requirements from Cadbury Schweppes that the Italian Presidency has in mind is, in my view, a step too far, because it does not take into account

\section{Notes}

170 Room document \# 1, Working party on Tax Questions - Direct Taxation, PSD - Anti-abuse rule, 24 Jul. 2014, p. 3, published in: Highlights \& Insights on European Taxation, H\&I 2015/274 (comments by Dennis Weber).

171 See, for instance, judgment of 30 Nov. 1995 in Case C-55/ 94 Gebhard, para. 25; judgment of 2 May 2006 in case C-341/04 Eurofood IFSC, paras 34 and 35; judgment of 12 Sep. 2006 in C-196/04 Cadbury Schweppes, para. 53.

172 'Reference can only be made to the criteria identified by the Court of Justice ....', according to the Italian Presidency.

173 Sep. 2006, case C-196/04, Cadbury Schweppes.

174 See, for example, Smit in: Tax competition in de EU, verslag van de 7de rondetafelbijeenkomst 'tax competition in de EU', para. 7.2.1. See also: B.J. Wolf \& A.Q.C. van Vuuren, De zaak-Fred Olsen en de aangepaste moeder-dochterrichtlijn: de substance-vereisten binnen het Europese misbruikconcept, WFR 7100 , p. 743 , which assume that under Art. 1, para. 2 of the moeder-dochterrichtlijn mainly a link will be sought with the substance-test in Cadbury Schweppes and Olsen. 
the fact that here there is other EU law and another abuse situation. The abuse such as was in discussion in Cadbury Schweppes was the artificial shifting of profits from one Member State to the other Member State (profit shifting), and the Italian Presidency applies the requirements, which the CJ has formulated to combat profit shifting to an arrangement, which tries to avoid withholding tax on dividend paid to third countries (directive shopping): an entirely different type of abuse.

If you share the opinion of the Italian Presidency that the case law about the EU Treaty freedoms is relevant for abuse under the PSD (especially the case law under the right of establishment), then it is important that it can be derived from the case law of the CJ under the right of establishment, that for the exercising of this right, economic activities are required in another Member State (in the example in the Member State where company B is established).

With regard to the activities of the intermediate holding company itself (company $\mathrm{C}$ ), under the treaty freedoms only marginal substance requirements are required and also more passive activities would seem to qualify. ${ }^{175}$ Also holding companies, for example, which only hold shares, can exercise the right of establishment. ${ }^{176}$ Under the case law concerning the treaty freedoms, the intermediate holding company itself does not have to perform economic activities. That is clearly shown from the Centros judgment, ${ }^{177}$ in which Danish nationals had incorporated a company in the United Kingdom, which then opened a branch in Denmark, for the purpose of avoiding Danish legislation requiring that a minimum amount of share capital be paid up. No activities whatsoever were performed in the UK. Nevertheless, in that case, the right of establishment could be invoked and this right was not abused: 'In that regard, it is immaterial that the company was formed in the first Member State only for the purpose of establishing itself in the second, where its main, or indeed entire, business is to be conducted', according to the CJ in paragraph 17 of Centros.

When thus (with the Italian Presidency) the opinion is that the Cadbury Schweppes case law is applicable to the application of the common anti-abuse rule in situations of directive shopping in order to avoid withholding tax, the consequence will be that an intermediate holding company will easily satisfy the (marginal) substance requirements due to which also under the ParentSubsidiary Directive there will be an economic reality and thus no question of abuse. ${ }^{178}$ As I have indicated above, this would not appear to be a correct interpretation of the common anti-abuse rule. This because first, the question is whether the substance requirements, which the CJ has developed under the Treaty freedoms are also applicable under the PSD and, furthermore, abuse can also be present when an entity has economic substance, but the holding of the shares as such has no economic reality.

\subsubsection{Another Approach to Directive Shopping}

Such as I argue here above, to me, the approach of the Italian Presidency when there is an economic reality of an interposed company in the case of alleged directive shopping is not the correct one.

The question is on the basis of what circumstances should the economic reality of the interposed company in fact be determined. The starting point is that this is dependent on the legislation, which is avoided and the type of transaction or arrangement (see further for this above in paragraph 7.2). ${ }^{179}$

To answer the question whether a dividend payment to an intermediate holding company is abuse, first the question must be asked whether the specified applicable directive provisions are being abused. What this hinges on, in my view, is whether a taxpayer who tries to satisfy the conditions of a certain tax advantage (in the subject case exemption from withholding tax), sets up an arrangement for this purpose which (i) is in conflict with the object and purpose of the conditions of obtaining the tax advantage, and (ii) is artificial. With regard to the exemption from withholding tax, it will particularly concern whether the conditions have been fulfilled such that there is an (i) EU cross border dividend payment (Article 1(1)(b) of the directive) and that the tax residence requirement has been fulfilled, to wit, that the company (ii) according to the tax laws of a Member State is

\section{Notes}

175 See in the same sense: M. Poulsen, Treaty/Directive Shopping and Abuse of EU Law, 4 Intertax 239 and 240 (2013).

176 See for a recent overview: F.P.G. Potgens \& M.J.E. Straathof, Vestiging en substance van (tussen) houdstercompanies vanuit EU-rechtelijke perspectief, MBB 2015, no. 2, p. 50.

177 See: D. Weber, Tax Avoidance and the EC Treaty Freedoms para. 2.2.5 (Kluwer Law International 2005) holding and letterbox companies within the EU.

178 ECJ 9 Mar. 1999, C-212/97, Centros.

179 See on this Smit in: Tax competition in the EU, report of the 7th round table meeting 'tax competition in de EU' para. 7.2.1. See also: B.J. Wolf \& A.Q.C. van Vuuren, De zaak-Fred Olsen en de aangepaste moeder-dochterrichtlijn: de substance-vereisten binnen het Europese misbruikconcept, WFR 7100, blz. 743. F.P.G. Potgens \& M.J.E. Straathof deal extensively with the fact that requirements, which the right of establishment sets for intermediate holding companies are marginal. See: F.P.G. Potgens \& M.J.E. Straathof, Vestiging en substance van (tussen) houdstermaatschappijen vanuit EU-rechtelijke perspectief, MBB 2015, nr. 2, blz. 50. 
considered to be resident in that Member State for tax purposes (Article 2(a)(ii) of the directive).

\subsubsection{EU Cross Border Dividend Payment}

If the Parent-Subsidiary Directive is to be applicable, there must be a case of a distribution of profits paid by an EU subsidiary to its EU parent company. Assume that a company in Member State $\mathrm{Y}$ pays a dividend to its intermediate holding company established in Member State $\mathrm{X}$ and on the same day, this intermediate holding company pays the same amount to its parent company in a third country. It can be questioned whether in such a situation there is in fact a matter of an $E U$ dividend. The economic reality entails that in fact, a dividend payment has been made by the company established in $\mathrm{Y}$ to the company established in a third country. In my view, economic substance requirements play a limited role here. In the example I gave above, I am of the view that the economic reality will entail that also when the intermediate holding company has substance (in the sense that economic activities take place); this does not have to mean that this is an EU dividend. ${ }^{180}$ There can only be an EU dividend when the intermediate holding company can decide independently to, for example, reinvest the dividend it has received (in or outside of the EU). If it has been established in advance that the intermediate holding company does not have this authority, then the economic reality will, in my view, entail that there is no question of an EU dividend. ${ }^{181}$ We also see suchlike reasoning in national Danish cases such as ISS, HHU, COOK and SKM 2012.409 LSR. ${ }^{182}$ Probably a link can also be sought here with the so-called 'significant people functions' of the intermediate holding company with regard to the economic interests of the shares. ${ }^{183}$

The question that herewith also arises is to what extent is it also important how much risk the intermediate holding company must run with regard to the activities, which it performs. ${ }^{184}$ It would seem defendable that went the intermediate holding company runs no risk whatsoever, the structure lacks economic reality. ${ }^{185}$ We see that, for example, in the SICES case, in which as indication that there was a matter of abuse, the CJ mentioned the lack of commercial risk. ${ }^{186}$ Also in the November 2013 proposal for a general anti-abuse rule, the lack of risk was mentioned as an indication of abuse. ${ }^{187}$

\subsubsection{Tax Residence}

The question can also be asked in what cases the tax residence requirement is circumvented. The national law of a Member State in combination with tax treaties as a rule allow that a holding company without substantial activities to have its tax residence in that Member State. The requirement that the tax residence is located in a Member State is often filled in as where the place of effective management of a company is situated. ${ }^{188}$ It will thus have to be verified whether the place where formally the statutory management is located also reflects an actual economic reality. ${ }^{189}$

In this framework, in my view, of importance is the competence of the actual management, the place where their decisions are taken and also the influence of the ultimate shareholders on their decisions. To see that suchlike criteria can be of importance, we look back at the Opinion of AG Leger in Cadbury Schweppes. In point 113 he observes: 'The second of those criteria relates to the genuine nature of the services provided by the subsidiary. In that connection, it is a question of looking at the competence of the subsidiary's staff in relation to the services provided and the level of decision-making in carrying out those services. If, for example, the subsidiary proves to be nothing but a mere tool of execution because the decisions necessary to carry out the services it is paid for are taken at another level, it is also right to consider that the subjection of those services to the tax sovereignty

\section{Notes}

180 See also: E. Picq, Abuse of EU Holding Companies: fundamental Freedoms, EC Parent-Subsidiary Directive and the French Constitution, - Part 1474 (ET 2009) and H. van den Hurk, De introductie van en algemene anti-abuse provision zet de Europese Unie jaren terug in de tijd, WFR 2014/7051, p. 732.

181 Marres and de Groot come to the same conclusion on the basis of another reasoning: O.C.R. Marres \& I.M. de Groot, De algemene antimisbruikbepaling in de moederdochterrichtlijn (deel 1), WFR 2015/7106, p. 893.

182 See also: M. Poulsen, Treaty/Directive Shopping and Abuse of EU Law, 4 Intertax 248 (2013); R.J.S. Tavares \& B.N. Bogenschneider, The New De Minimis Anti-Abuse Rule in the Parent-Subsidiary Directive: Validating EU Tax Competition and Corporate Tax Avoidance?, 8\&9 Intertax 487 (2015).

183 See: J. Bundgaard, Danish Case Law Developments on Beneficial Ownership, Tax Notes International 63 (1 Oct. 2012).

184 OECD-report on the attribution of profits to permanent establishments, 2008 and 2010. See also: O.C.R. Marres \& I.M. de Groot, De algemene antimisbruikbepaling in de moeder-dochterrichtlijn (deel 1), WFR 2015/7106, p. 893

185 See also: Communication from the Commission, The application of anti-abuse measures in the area of direct taxation - within the EU and in relation to third countries, Brussels 10.12.2007, COM (2007) 785 final, p. 4.

186 See: M. Poulsen, Treaty/Directive Shopping and Abuse of EU Law, 4 Intertax 248 (2013).

187 13 Mar. 2014, SICES, case C-155/13, para. 39.

188 As indicated that there is no question of an economic reality it is observed: 'the arrangement results in a significant tax benefit which is not reflected in the business risks undertaken by the taxpayer or its cash flows'.

189 See: G. Maisto (ed.), Residence of Companies under Tax Treaties and EC Law (EC and International Series, No. 5, IBFD 2009); See as concerns the Netherlands: J. Gooijer, Vestiging van (tussen) houdstercompanies in Nederland: substancevoorwaarden in tax treaties?, MBB 2015/2, blz. 39. 
of the host State constitutes a wholly artificial arrangement'. In the final judgment in Cadbury Schweppes this more substantive test (such as proposed by the AG) is not to be found, ${ }^{190}$ although the $\mathrm{CJ}$ does refer to the Eurofood case. This case concerned the question whether Eurofood was a letterbox company. In order to examine this, the question was who ultimately 'administered the policy of the subsidiary'. In that framework, the CJ pointed out that there can be no question of a letterbox company by the mere fact that its economic choices are or can be controlled by a parent company in another Member State. Another and a more concrete example is in the Planzer judgment, ${ }^{191}$ which concerned the interpretation of the term 'place of business' in Article 1(1) of the 13th VAT Directive. Also in this case, it concerned essentially the question of where policy of the company was determined. In this case, the CJ also made a parallel with letterbox companies and referred to Eurofood and Cadbury Schweppes. In paragraphs 60-62, the CJ considered:

With regard to a company, as in the case in the main proceedings, the term business for the purposes of Article 1(1) of the Thirteenth Directive refers to the place where the essential decisions concerning the general management of that company are adopted and where the functions of its central administration are carried out.

Determination of a company's place of business requires a series of factors to be taken into consideration, foremost amongst which are its registered office, the place of its central administration, the place where its directors meet and the place, usually identical, where the general policy of that company is determined. Other factors, such as the place of residence of the main directors, the place where general meetings are held, the place where administrative and accounting documents are kept, and the place where the company's financial, and particularly banking, transactions mainly take place, may also need to be taken into account.

Thus, 'a fictitious presence, such as that of a "letter box" or "brass plate" company, cannot be described as a place of business for the purposes of Article 1(1) of the Thirteenth Directive (see, by analogy, Case C341/04 Eurofood IFSC [2006] ECR I3813, paragraph 35, and Cadbury Schweppes and Cadbury Schweppes Overseas, paragraph 68).'

In these cases, the $\mathrm{CJ}$ put the question where ultimately the policy of the company was determined (this thus is close to the effective place of management) against the being of a letter box company. General economic substance requirements are not made, but the requirements are tuned to the conditions, which were under discussion in that case. Also, with regard to the tax residence in the Parent-Subsidiary Directive, no economic substance requirement is set in the directive; it would thus be contrary to the scope of the provision to make such a requirement. ${ }^{192}$ That was different, for example, in the proposal (not in the text, which was finally adopted) of the Interest \& Royalty Directive from 1998. In this proposal, for the question when was there a 'company of a Member State' an economic nexus requirement was made, to wit, that the activities of the company 'present an effective and continuous link with the economy of that Member State'. ${ }^{193}$ It also does not follow from primary Community law, for that matter, that a company must always have an economic link with a Member State. ${ }^{194}$

Moreover, it must be noted that the tax residence such as is referred to in the Parent-Subsidiary Directive must be determined 'according to the tax laws of a Member State'. This in my view, however, does not mean that the Member States are entirely at liberty to lay down conditions for tax residence. In the subject case, in my view, there is a

\section{Notes}

190 See also: Communication from the Commission, The application of anti-abuse measures in the area of direct taxation - within the EU and in relation to third countries, Brussels 10.12.2007, COM (2007) 785 final, p. 4.

191 In EFTA Court 9 Jul. 2014, no E-3/13, Olsen, H\&I 2014/288 (comments by Daniel Smit). The EFTA court applied, compared to Cadbury Schweppes, a more substantive test. In the Olsen case of het EFTA court, the decision in Cadbury Schweppes was confirmed and supplemented further with the following consideration: (para. 99): 'Whether the entity in question conducts a real and genuine economic activity cannot be answered in the abstract. It depends on the actual terms of the entity's statutes, such as, in the case at hand, the trust's deed, and the actual activities of that entity and its management. If a specific assessment reveals, for example, that the trust is involved in the management of a group's companies or other activities for a group, such as managing a pool of resources, and its actual incorporation reflected its actual activities, it has to be regarded as a real and genuine economic activity, which constitutes establishment. As the Commission stated in response to a question from the bench, it is not required that the economic activities take effect in the EEA State of establishment. It suffices that they take effect in the EEA'. We see from this consideration that the substance test in Cadbury Schweppes is more in-depth, and does not only examine whether staff members (etc.) are on the payroll, but also actual testing must take place into the substantive work of these persons; See for a substantive test also: L. de Broe, International tax planning and prevention of abuse, IBFD, 2008, p. 853. See further on this case: B.J. Wolf en A.Q.C. van Vuuren, De zaak-Fred Olsen en de aangepaste moeder-dochterrichtlijn: de substance-vereisten binnen het Europese misbruikconcept, WFR 7100 , blz. 734 en O.C.R. Marres, CFC-regels, trust en verkeersvrijheden, NTFR 2014/42.

192 CJ 28 Jun. 2007, case C-73/06, Planzer.

193 A parallel can be drawn with CJ 9 Mar. 1999, C-212/97, Centros. In this case, the Danish trade register also applied an economic activities requirement for the registration of a company in het Danish trade register. The CJ found that such a requirement is contrary to the object of the right of establishment, which does not provide for such a requirement for the incorporation of companies.

194 See: Art. 3(1)9a(i) of the proposal. COM (1998) 67 final, Brussels, 04.03.1998. See also: D. Weber, The Proposed EC Interest and Royalty Directive, 1 EC Tax Rev. 15 (2000) 
quasi-national interpretation, which means that the Member States are at liberty to substantiate, but must remain within the objective of the provision. ${ }^{195}$

Be that as it may, I do not think that an economic substance or nexus test should be read into a tax residence requirement such as in Article 2(a)(ii) of the ParentSubsidiary Directive on the basis of the common antiabuse rule. It should only be asked whether the tax residence reflects in a specific case an economic reality. In addition, requirements must be made, which are in line with the definition of 'tax residence'.

In short, on the basis of the above, the economic reality of a cross border EU dividend or of the tax residence must be determined. The circumstances, which I have formulated, which are thereby relevant, are not so much 'economic substance/commercial reality/economic activity' requirements, such as these are called by the Italian Presidency, but are attuned more to the specific abuse (directive shopping in relation to third States) and to the provisions of the Parent-Subsidiary Directive, which are circumvented.

\section{Consequence of abuse}

\section{I Not Granting Directive Benefits}

Article 1, paragraph 2 determines: 'Member States shall not grant the benefits of this Directive to an arrangement'. The consequence of the fact that there is abuse, therefore, is the not granting of the benefits of the directive. It is important to recognize that the benefits may not be granted 'to an arrangement' or a 'series of arrangements'. Such as remarked above in paragraph 6.2 there is thus no link with the taxpayer ('company of a Member State'). This, in my view, means that the benefits must be refused to the arrangement, which constitutes abuse and not so much to the taxpayer involved. It also appears from the 'to the extent approach' that the abuse must be combated insofar as certain part ('step or part') of an arrangement constitutes abuse.

\subsection{To the Extent Approach}

The directive follows the so-called 'to the extent approach'. In Article 1, paragraph 2 it is observed 'An arrangement may comprise more than one step or part' en in paragraph 3 'For the purposes of paragraph 2, an arrangement or a series of arrangements shall be regarded as not genuine to the extent that they are not put into place for valid commercial reasons which reflect economic reality'.

In consideration 8 of the preamble to the directive, this is called the 'to the extent approach'. Consideration 8 reads as follows: 'While Member States should use the anti-abuse clause to tackle arrangements which are, in their entirety, not genuine, there may also be cases where single steps or parts of an arrangement are, on a standalone basis, not genuine. Member States should be able to use the anti-abuse clause also to tackle those specific steps or parts, without prejudice to the remaining genuine steps or parts of the arrangement. That would maximise the effectiveness of the anti-abuse clause while guaranteeing its proportionality. The "to the extent approach" can be effective in cases where the entities concerned, as such, are genuine but where, for example, shares from which the profit distribution arises are not genuinely attributed to a taxpayer that is established in a Member State, that is, if the arrangement based on its legal form transfers the ownership of the shares but its features do not reflect economic reality'.

With the 'to the extent approach' it is clear that also parts of an arrangement can be considered abuse. This is in accordance with cases such as Thin cap GLO, ${ }^{196}$ Halifax $^{197}$ and Weald Leasing. ${ }^{198}$ In the example from consideration 8 of the preamble, it appears that when the entities in which shares are held are as such genuine, this does not have to mean that the holding of the shares themselves is also genuine (see further on the example from the preamble, paragraph 7.3.).

On the basis of the 'to the extent approach', in the case the ultimate purpose of a certain arrangement is commercial/business, but the route followed in order to achieve this ultimate purpose constitutes abuse, the route followed can be separately considered as abuse. This, in my view, can also be derived from the fact that Article 1, paragraph 2 mentions an arrangement with as 'main purpose or one of the main purposes' of obtaining a tax advantage. This wording namely provides scope in the case the ultimate purpose has a business reason, but still to consider the route followed as one of the main purposes for obtaining a tax advantage. Under the anti-abuse provision

\section{Notes}

195 A holding company, which is incorporated under the law of a Member State, may exercise the right of establishment. To do so, according to the case law, it is not required that the holding company itself conducts economic activities (cf. Centros, C-212/97). This is different when a company has only its registered office in the Community and its central administrative or principle place of business outside of the Community. In such a situation, the holding may not exercise the right of establishment unless, the activity 'shows a real and continuous link with the economy of a Member State'. See: C-208/00, Uberseering, para. 75 and the Council General Programme for the abolition of restrictions on the right of establishment of 18 Dec. 1961, OJ, English special edition, second series (IX), p. 7. that a holding company only has its registered office in a Member State will not so readily occur when for the determination of the place of residence a Member State links this to the effective place of management. See also: D. Weber, Tax Avoidance and the EC Treaty Freedoms, para. 2.2.5 (Kluwer Law International 2005), holding and letterbox companies and third Countries. 
of the Merger Directive (which mentions 'principle objective or as one of its principle objectives' and thus is comparable on that point) application of the 'to the extent approach' was under discussion in the Zwijnenburg case. ${ }^{199}$ In that case, the interested parties wanted to bring two buildings together in one company by means of a company merger. In that case, the Hoge Raad (Supreme Court) assumed that avoidance of transfer tax was the principle objective of the intended company merger. True, the combining of the buildings in one single company was prompted by business considerations, but not the chosen detour of the company merger. Here the Hoge Raad applied (tacitly) the to the extent approach under the Merger Directive. AG Kokott dismissed the approach of the Hoge $\operatorname{Raad}^{200}$ because it would excessively restrict the economic freedom; a taxpayer, namely, is free in the case there are a number of legally permissible set-ups available to achieve a certain economic goal, to chose the option in which he pays less tax, according to the AG.

In the final judgment in the Zwijnenburg case, the CJ was silent on this problem given that it was not part of the question referred by the Netherlands Supreme Court to the $\mathrm{CJ}$ for a preliminary ruling. Whether you agree or not with the interpretation of AG Kokott in Zwijnenburg, ${ }^{201}$ it is clear that under the anti-abuse rule in the ParentSubsidiary Directive the route followed can indeed be considered abuse. I note thereby that this route, if there is to be abuse, must not have any economic reality. The fact that the route followed was chosen only for tax reasons is not sufficient to indicate that route as abuse. In this respect this can, also for the PSD, fit in with the Opinion of AG Kokott in Zwijnenburg in which she emphasizes that a tax reason for a certain route does not in itself constitute abuse.

\subsection{Ignore the Arrangement: No Fall Back on Advantageous Tax Treaty}

As has been observed, the Member States must in the case of abuse within the meaning of Article 1, paragraph 2: 'not grant the benefits of this Directive to an arrangement'. The question is how this must be done. Such as I have indicated in paragraph 5.2., I am of the view that the directive also extends to bilateral tax treaties. In the case of abuse, the Member States must thus refuse the directive benefits (for example, an exemption from withholding tax) in accordance with their national law, but may not in addition on the basis of a bilateral treaty still grant a lowered withholding tax on dividend (for example, to zero percent). If they do this, this would infringe Article 1, paragraph 2 (see in this regard also paragraph 5.3. about the prohibition of inverse direct effect).

The most obvious consequence to combat abuse is that the arrangement, which is considered abusive has to be ignored. In the example in the Questions and Answersmemo to the November proposal, ${ }^{202}$ it is also assumed that when there is a matter of the interposing of a 'letterbox company with no substance' between an EU Member State and a third country, this letterbox company must be ignored. ${ }^{203}$

Imagine, for example, that between Member State Spain and the United States a 'letterbox company with no substance' in the Netherlands is interposed. This in order to avoid the Spanish withholding tax on dividend paid to the US. Assume that this letterbox company must be considered artificial and constitutes an arrangement, which has as main purpose obtaining a tax advantage, which is in conflict with the object and purpose of the directive. In order to remove this abuse, the situation must be re-established in which Spain can levy withholding tax on a dividend paid to the US. This is achieved by ignoring the arrangement (in the subject case, the letterbox company in the Netherlands). The consequence of this is that a dividend is seen, which is paid directly from Spain to the US and (just as before the abusive interposing of the subholding) the national tax law of Spain is applicable and thus the tax treaty between Spain and the US (and the possibly lowered withholding tax rate in that treaty).

\section{Notes}

199 CJ 22 Dec. 2010, case C-103/09, Weald Leasing, H\&I 2011/3.10 (comments by De la Feria), para. 51.

200 Opinion in case C-352/08, Zwijnenburg, point 43-47.

201 AG Kokott observed on this: "43. The Netherlands courts are therefore drawing a distinction here between the commercial aim of bringing two buildings within one single company, which they consider legitimate, and the merger route chosen for that purpose, which they consider to be an abuse. 44 . It seems to me that drawing such a distinction between aim and method excessively restricts economic freedom. A whole number of legally permissible set-ups might often be available to enable a legitimate economic proposal to be achieved, some of which might prove to have a more favourable tax regime than others. The fact that the parties ultimately choose the option that is most favourable for tax purposes cannot by itself be sufficient grounds on which to base charges of tax avoidance under Article 11(1)(a) of Directive 90/434. 45. Ultimately, that provision just reflects the general Community law principle that abuse of rights is prohibited. Conduct merely taking advantage of the options presented by Community law - in this case by Directive 90/434 - cannot by itself justify suspicion of abuse or tax avoidance. 46. In the light of the foregoing the referring court will again have to examine whether the proposed merger in this case might not have been based on valid commercial reasons, particularly when one considers that it might have served to restructure or rationalise the companies run by Members of the Zwijnenburg family and was also a legal means of achieving the economic aim, which was to bring the two properties at Tolstraat 17 and Tolstraat 19 within a single company. 47. It must be concluded, in summary, as follows: The mere fact that in order to achieve a legitimate economic aim a taxpayer chooses, out of several lawful options, the one that is most favourable to it for tax purposes is not by itself sufficient grounds for a charge of tax avoidance within the meaning of Article 11(1)(a) of Directive 90/434.

202 It would seem to follow from the Opinion of Kokott that she assumed that under the Netherlands case law abuse existed when the route followed was chosen for tax reasons. That, however, is incorrect; if abuse is to exist, then this route must also have something artificial. Kokott was thus critical of the Netherlands case law, but this case law is stricter than she assumed. See on this case law: R.J. de Vries, Kwaliteit van fiscale rechtsvinding en fiscaal regelgeving, WFR 2010.

203 Question and Answers on the Parent-Subsidiary Directive, Brussels, 25 Nov. 2013, MEMO/13/1040. 
This would seem the most suitable route to remove the abuse. It is important to realise that in this approach, the tax treaty between Spain and the Netherlands (probably with a lower withholding tax percentage on dividend) is then not applicable 204205 .

Such an approach is in accordance with VAT cases such as Weald Leasing, ${ }^{206}$ in which the CJ considered (paragraphs 50 and 51): 'If that were the case, it would, secondly, be for that court to redefine those transactions so as to re-establish the situation that would have prevailed in the absence of the elements constituting that abusive practice. Thus, if the national court concluded that certain contractual terms of the leasing transactions at issue in the main proceedings and/or the intervention of Suas in those transactions constituted an abusive practice, that court would have to redefine those transactions disregarding the existence of Suas and/or by varying or disapplying those contractual terms'.

\subsection{Proportionate Consequence: No Mutual Recognition of Abuse - Double Taxation}

The consequence of abuse must be proportional and thus be applied in accordance with the principle of proportionality. This is settled case law of the CJ under the Treaty freedoms (for example, Thin Cap Group Litigation) 207 and in VAT (Halifax) ${ }^{208}$ and this means, amongst others, that the consequence of abuse may not go farther than is necessary in order to ensure that the correct levy of corporate taxation of dividend is levied.

This means for the common anti-abuse rule that when there is an arrangement in which withholding tax on dividend is avoided, in my view, only this abuse must be combated by still levying withholding tax in the source State. It would be disproportionate when, besides this, the resident State in such a situation is also obliged not to grant prevention of economic double taxation (by, for example, not applying the participation exemption). ${ }^{209}$ The tax levy in the resident State (corporate taxation) would namely, in a situation in which withholding tax on dividend is avoided, in principle, not be avoided. Under the Parent-Subsidiary Directive, there is also no obligation of mutual recognition of the decisions of the tax authorities of another Member State. Thus, in a situation in which the source State is of the opinion that there is abuse, the resident State is not obliged to follow this opinion.

When there is abuse and the source State, for example, withholds a withholding tax on a dividend paid to a subholding (which the source State considers an abusive arrangement), there is a risk of double taxation. Assume that Holding A established in a non-EU Member State holds $100 \%$ of the shares in subholding B established in EU Member State B. Subholding B, in turn, holds 100\% of the shares in company C. The EU Member State in which company $\mathrm{C}$ is established considers subholding $\mathrm{B}$ an abusive arrangement under the common anti-abuse rule and levies a withholding tax on dividend. The Member State in which subholding B is established probably does not provide for prevention of double taxation for the withholding tax because it exempts the dividends, the non-EU Member State where Holding A is resident, in its turn, probably also does not give any credit for the withholding tax on the dividend because this concerns a dividend to which Holding $\mathrm{A}$ is not directly (but indirectly) entitled. This can give rise to double taxation. This problem could be removed when the State of Holding A would consider the dividend as a dividend to which holding $\mathrm{A}$ is directly entitled, and this would prevent double taxation. It cannot be derived from the PSD, however, that this State is under such an obligation, certainly not when the State in which Holding A is established is a non-EU State and thus, the PSD is not applicable. In the VAT case, WebMindLicenses, ${ }^{210}$ the threat of double taxation in the case of abuse was also under discussion. In that case, AG Wathelet was of the opinion that double taxation could only be avoided when EU law obliged the tax authorities of the Member States to mutually recognize their respective decisions. Given that such an obligation does not exist within the VAT, double taxation as a result of abuse is an unavoidable consequence. Given the fact that also under the Parent-Subsidiary Directive such obligation of mutual recognition does not exist, the outcome would be the same.

\section{Notes}

204 See also the Recommendation of the Commission on aggressive tax planning: 'An artificial arrangement or an artificial series of arrangements which has been put into place for the essential purpose of avoiding taxation and leads to a tax benefit shall be ignored. National authorities shall treat these arrangements for tax purposes by reference to their economic substance'.

205 Different: Smit in: Tax competition in de EU, verslag van de 7de rondetafelbijeenkomst 'tax competition in de EU' para. 7.2.1 and F. Debelva \& J. Luts, The General AntiAbuse Rule of the Parent-Subsidiary Directive para. 3.3.2 (IBFD ET 2015).

206 An interesting question is also how the Member States will now precisely give form to the impact of the common anti-abuse rule under tax treaties. See about this s. 5.3.

207 CJ 22 Dec. 2010, case C-103/09, Weald Leasing, H\&I 2011/3.10 (comments by De la Feria), para. 51

208 CJ 13 Mar. 2007, C-524/04, Thin Cap Group Litigation, para. 83

209 Halifax, para. 92

210 See also: O.C.R. Marres \& I.M. de Groot, De algemene antimisbruikbepaling in de moeder-dochterrichtlijn (deel 2), WFR 2015/7107, p. 915 


\section{Closing remarks}

In this paper, I have dealt with the background, impact, applicability, object and effect of the new mandatory 'common minimum anti-abuse rule', which is incorporated in the EU Parent-Subsidiary Directive.

Due to this amendment, it is the first time that it has been made mandatory to incorporate a General AntiAbuse Rule (GAAR) in the tax legislation of the EU Member States. The common minimum anti-abuse rule is aimed at supplementing, without replacing, the domestic and agreement-based provisions to prevent tax avoidance, thereby granting a minimum EU standard for the purposes of protecting the PSD. The rule can be described as a 'de minimis rule' but is no carte blanche for the Member States to apply further-reaching national antiabuse measures than the minimum abuse, which the antiabuse rule prescribes.

Implementation of the anti-abuse rule in my view, must take place in legislation (thus not by means of unwritten abuse case law), and must also extend to tax treaties. If a Member State does not extend the application of the antiabuse rule to a tax treaty (not by way of implementing it in a tax treaty or not by way of treaty override by national law) the tax administration cannot take away the benefit (for instance, a lower withholding tax) on the basis the direct application of the common anti-abuse rule because of the prohibition of inverse direct effect of directives.

On the basis of the consistency, which the common anti-abuse rule endeavours to effect, it is defendable that the provision must be implemented literally in the legislation of the Member State, but the expectation is that many Member States will substantiate the so-called not genuine (economic reality) test by the setting of substance requirements. The anti-abuse rule must be implemented both for the withholding tax on dividend and for the participation exemption/credit method. The European Commission has indicated in a Statement that the amendment will not affect national participation exemption systems and thus does not have to be implemented for participation exemption systems, but to me, the legal effect of this Statement would seem to be lacking given that the Statement is not included in the text of the directive itself and also not in the preamble to the directive.
The general anti-abuse provision provides for three tests that must be satisfied in order to come to the conclusion that there is a matter of abuse:

- Main purpose test.

- Conflict with the object and purpose test.

- Not genuine (artificiality)/economic reality test.

The most common case that the anti-abuse is trying to prevent is the avoidance of withholding tax on dividend paid to companies established in third countries. Those types of structures (whereby withholding tax is avoided by incorporating an intermediate holding company in the EU) will be the most affected by the amendment. On the basis of what criteria suchlike structures can be combated is not clear. During the formation of the directive, the Italian Presidency pointed out that in particular, economic substance requirements are relevant and linked to the substance criteria from the Cadbury Schweppes judgment of the CJ. In my opinion, the criteria to combat such structures, however, should rather be attuned to the alleged abuse (directive shopping) and attuned to the provisions that are circumvented.

The scope of the anti-abuse rule, for that matter, is not limited to directive shopping in order to avoid withholding tax on dividend to non-EU countries. The text of the anti-abuse rule is broader, thus other abuse can also be affected.

In my view, the consequence of abuse under the antiabuse rule must be that the artificial arrangement be ignored, both for the national law, and for the application of the tax treaty. The consequence of this, amongst others, is that in the case of abuse, we cannot fall back on a tax treaty, which grants the same benefits (in particular, exemption or lowering of withholding tax) as the ParentSubsidiary Directive.

I wish to note in conclusion, that due to the absence of an explanatory memorandum to the introduction of a common minimum anti-abuse provision, the precise scope and consequences are uncertain. With this contribution, I hope to further stimulate deliberations on the impact, scope and the consequences of the anti-abuse rule. 